\title{
Ghrelin Response to Acute and Chronic Exercise: Insights and Implications from a Systematic Review of the Literature
}

\author{
Nejmeddine Ouerghi ${ }^{1,2}$ (D) Moncef Feki ${ }^{2}$ (D) Nicola Luigi Bragazzi ${ }^{3} \cdot$ Beat Knechtle $^{4,5}$ (D) Lee Hill $^{6}$. \\ Pantelis T. Nikolaidis ${ }^{7} \cdot$ Anissa Bouassida ${ }^{1}$
}

Accepted: 5 July 2021 / Published online: 10 August 2021

(c) The Author(s) 2021

\begin{abstract}
Background Ghrelin is a peptide hormone predominantly produced by the stomach. It exerts a wide range of functions including stimulating growth hormone release and regulating appetite, food intake, and glucose and lipid metabolism. Since physical exercise affects all these aspects, a particular interest is accorded to the relationship between ghrelin and exercise. This systematic review aimed to summarize the current available data on the topic for a better understanding of the relationship. Methods An extensive computerized search was performed in the PubMed and SPORTDiscus databases for retrieving relevant articles. The search contained the following keywords: ghrelin, appetite-related peptides, gastrointestinal peptides, gastrointestinal hormones, exercise, acute exercise, chronic exercise, training, and physical activity. Studies investigating the effects of acute/chronic exercise on circulating forms of ghrelin were included.

Results The initial search identified 840 articles. After screening, 80 articles were included. Despite a heterogeneity of studies and a variability of the findings, the review suggests that acute exercise suppresses acyl ghrelin production regardless of the participants and the exercise characteristics. Long- and very long-term exercise training programs mostly resulted in increased total and des-acyl ghrelin production. The increase is more noticeable in overweight/obese individuals, and is most likely due to weight loss resulting from the training program.

Conclusion The review suggests that exercise may impact ghrelin production. While the precise mechanisms are unclear, the effects are likely due to blood flow redistribution and weight loss for acute and chronic exercise, respectively. These changes are expected to be metabolically beneficial. Further research is needed for a better understanding of the relationship between ghrelin and exercise.
\end{abstract}

\section{Introduction}

Ghrelin is a peptide hormone predominantly produced by the stomach with lower amounts being synthesized in the intestine, pancreas, and in other organs [1]. Ghrelin was identified 20 years ago as an endogenous ligand able to bind to the orphan growth hormone secretagogue receptor (GHSR-1a) and to stimulate growth hormone $(\mathrm{GH})$ secretion via a novel pathway [2]. Since this date, domains of actions and interest in this peptide have expanded greatly. Notably, it has been recognized to play a key role in stimulating both appetite and energy intake. Ghrelin is present in two endogenous peptide

Beat Knechtle

beat.knechtle@hispeed.ch

Extended author information available on the last page of the article variants: acyl ghrelin (AG) and des-acyl ghrelin (DAG). The circulating AG:DAG ratio varies from 1:4 to 1:9 according to physiological factors such as body composition and nutritional status [3-5], while the underlying mechanisms are poorly understood. AG is formed by post-translational addition of a medium chain fatty acid, typically octanoate or decanoate, to the third $\mathrm{N}$-terminal amino acid residue, a modification catalyzed by ghrelin-O-acyltransferase (GOAT) [6]. GOAT has been detected in the human serum, the hippocampus, and the temporal gyrus [7,8]. AG can be locally formed by GOAT, which presumably allows it to exert effects in selected tissues and brain areas [8]. AG recognizes and binds to GHSR-1a to exert the primary hormonal and metabolic actions of ghrelin [2]. DAG derives from the proteolytic processing of unacylated proghrelin by prohormone convertase $1 / 3$ or from cleavage of an acyl radical from AG 


\section{Key Points}

Ghrelin is an orexigenic gastrointestinal hormone composed of two isoforms-namely acyl and des-acyl ghrelin, which exert both analogous and opposite effects on metabolism.

Literature data on the effects of physical exercise on ghrelin production are controversial due to the heterogeneity of the studies, making an accurate interpretation of outcomes challenging.

Acute exercise is generally associated with the suppression of acyl ghrelin, while prolonged training resulted in increased total and des-acyl ghrelin, most likely due to weight loss.

Exercise-induced changes in ghrelin isoforms, namely decreased acyl ghrelin and increased des-acyl ghrelin, are expected to be metabolically beneficial.

by esterases such as butyrylcholinesterase [3,9]. This form is unable to bind and activate the GHSR. However, it has been proven to exert diverse metabolic effects, especially on insulin sensitivity and glucose and lipid metabolism via unidentified receptors that DAG might share with AG [10, 11]. Some of these effects may modulate and even antagonize AG effects [12, 13].

Beyond the regulation of appetite, GH secretion, and the metabolism, ghrelin is involved in the modulation of gastric and gut secretion and motility, sleep-wake rhythm, and food/ reward behavior $[9,14,15]$. The most well-known effect of ghrelin is the stimulation of appetite, via the activation of orexigenic hypothalamic neurocircuits, which results in an increase in body weight and adiposity. Upon fasting, hypoglycemia, or fat depletion, ghrelin is secreted into the circulation, transported across the blood-brain barrier, and binds to neurons in the hypothalamus and extra-hypothalamic regions, as well as in metabolic organs, resulting in a stimulation via diverse pathways of appetite and initiation of food intake [9]. Ghrelin's metabolic effects have received increasing interest since pharmacological modulation of ghrelin signaling was found to be a potential therapeutic strategy to fight against diabesity and insulin resistance. Ghrelin has been proven to suppress insulin secretion [16, 17], to impair insulin sensitivity in healthy humans $[18,19]$, to reduce glycogen genesis and activate gluconeogenesis in the liver [20], and to stimulate glucose output from hepatocytes [21]. Mice deficient in ghrelin or in its receptor show a better glucose tolerance and insulin sensitivity [22, 23]. However,
GHS-R1a antagonists enhance insulin secretion and improve glucose tolerance in diet-induced or genetically manipulated obese animals [24, 25]. Ghrelin has been proven to enhance adipogenesis, to augment fat storage enzyme activity, to increase white adipose tissue mass in selective abdominal depots (retroperitoneal and inguinal), and to reduce fat utilization/lipolysis [26-28]. In reality, the biological effects might vary according to the ghrelin isoform; the two isoforms exert either analogous or antagonist effects. Both AG and DAG induced cell survival and protected against apoptosis in animal and human pancreatic $\beta$-cells [29]. However, AG-induced suppression of insulin secretion and hyperglycemia are prevented by co-administration of DAG [18]. DAG was shown to improve insulin sensitivity [30], to promote $\beta$-cell survival and to prevent streptozotocin-induced $\beta$-cell damage [31]. AG stimulates whereas DAG inhibits glucose output from hepatocytes [21]. Both isoforms seem to stimulate lipid accumulation in human visceral adipocytes [32]. However, they exert opposing effects on medium-chain fatty acid uptake; DAG increases the uptake whereas neither AG alone nor in combination with DAG does so [33].

Ghrelin production is regulated by hormones, neurotransmitters, lipid mediators, and diverse metabolites [9]. Its secretion is entrained to habitual eating patterns in humans. Circulating levels peak before feeding, drop thereafter in parallel with ingested energy, and then decline post-prandially [34]. Not only food per se, but also its composition, influences secretion. Exposure to high glucose or long-chain fatty acids suppresses [35], whereas specific amino acids (e.g., alanine, phenylalanine, glutamate) [36] stimulate, ghrelin release. The autonomic nervous system is another regulator of ghrelin secretion. The activation of sympathetic nerves and cholinergic agonists stimulates, while adrenergic and cholinergic antagonists suppress, ghrelin secretion [37-39]. Circulating ghrelin levels are influenced by body composition and metabolism, which modulate production as well as distribution of isoforms. Circulating ghrelin concentrations negatively correlate with body mass index, being lower in obesity and higher in emaciation [40, 41]. Obesity is associated with decreased levels of DAG and increased or normal levels of AG [20,32]. Plasma insulin and the homeostasis model assessment of insulin resistance index (HOMA-IR) correlate negatively with DAG, but positively with AG and AG:DAG ratio [20, 32].

Physical exercise is undoubtedly beneficial for health. However, the mechanisms that mediate its positive effects are not fully understood. Since both ghrelin and exercise have an impact on body composition, energy homeostasis, and glucose and lipid metabolism, interest has developed in investigating how physical exercise affects ghrelin secretion. Numerous studies investigated how ghrelin production 
is affected by acute and chronic exercise. The research has yielded inconsistent data, with an increase, a decrease, or no change in circulating ghrelin levels reported in response to acute or chronic exercise. Few previous reviews have summarized available data attempting to clear up the effects of exercise/training on ghrelin secretion [42-44]. They provided evidence suggesting that acute exercise transiently suppresses AG production while chronic exercise seems not to influence ghrelin levels independently of weight loss. However, an indisputable response could not be obtained due to the sparseness of data and the inconsistency of study results. On the other hand, previous reviews were not systematic and somewhat old, with the latest dating back 7 years. Since then, more studies have addressed the topic and further data on the subject have become available. In this context, we undertook a systematic literature review for an updated viewpoint on the effect of exercise/training on ghrelin production. Our purpose was to recognize how exercise affects ghrelin isoforms production and how potential changes affect the metabolic risk, and ultimately identify potential characteristics of individuals and exercise that are associated with healthy ghrelin change.

\section{Methods}

A comprehensive systematic review was conducted and reported according to the Preferred Reporting Items for Systematic Reviews and Meta-Analysis (PRISMA) guidelines [45]. Studies eligible for inclusion were those investigating the effect of acute and chronic physical exercise on circulating ghrelin levels in humans.

\subsection{Eligibility Criteria}

Studies were included if they satisfy the following criteria: (1) published in English in a peer-reviewed journal; (2) involved participants whatever their sex, age, body composition, physical fitness, and health status; (3) applied physical exercise intervention alone or combined with other intervention; (4) used acute or chronic exercise of different type, intensity, and duration; and (4) included at least two measurements (pre- and post-exercise/training) of ghrelin whatever the form detected. Studies were excluded if they: (1) did not meet the requirements of an experimental study design (e.g., reviews, case-reports, comments, opinions, editorials); (2) applied intervention with no physical exercise; (3) lacked information regarding exercise/training characteristics (e.g., type, intensity, frequency, duration); (4) used exogenous ghrelin administration; or (5) involved animals.

\subsection{Literature Search Strategy}

Literature searches were conducted in PubMed and SPORTDiscus databases from inception up to December 2020. The following key terms were included and combined using the operators "AND", "OR": ("ghrelin" OR "appetite-related peptides" OR "gastrointestinal peptides" OR "gastrointestinal hormones") AND ("exercise" OR "acute exercise" OR "chronic exercise" OR "training" OR "physical activity"). Further relevant studies were detected among the reference lists of the identified full-text papers, as well as through a search in similar articles and citations (PubMed database). Due to the large heterogeneity of included studies in terms of participants and exercise characteristics and the form of ghrelin detected, a systematic review and not a meta-analysis was performed.

\subsection{Study Selection}

Titles identified using the literature search described above were independently screened by two authors (NO and MF) based on inclusion and exclusion criteria. Citations with potential relevance were screened at the abstract level. When abstracts indicated potential inclusion, full-text articles were reviewed. For each eligible study, relevant information was extracted including sample size, participant characteristics (i.e., sex, age class, body mass phenotype, level of fitness/ training, health condition), exercise modality (i.e., acute, chronic), type (i.e., aerobic, resistance, intermittent, combined), intensity (i.e., moderate, intense) and duration, and analytical characteristics (i.e., ghrelin form detected, method of analysis, precision). The main outcome was the amount and direction of circulating ghrelin change. Changes in circulating GH and in body weight/body fat were also extracted when available. Any disagreement between the two authors in the selection of studies or the extracted data was resolved by discussion and consensus among all authors.

\section{Results}

\subsection{Selected Studies}

The literature search identified 840 records. After screening of titles, abstracts, and full texts, 80 relevant studies [46-125] were identified and included in the final analysis (Fig. 1). A summary of study characteristics and findings by exercise mode (acute or chronic) and duration (short-, longor very long-term) is presented in Tables 1 and 2. 


\subsection{Participant Characteristics}

Several studies included more than one arm, in which participants differed by sex, age class, body composition, training level, or applied exercise. Most studies $(n=57)$ were conducted in youth/young adults while 13 , seven, and three studies were conducted in adults, elderly subjects, and children, respectively. Most studies $(n=41)$ involved males while 16 studies involved females only, and 23 studies involved individuals of both sexes. Participants were normal weight people in 46 studies, overweight/obese people in 28 studies, and both groups in two studies. Five studies involved clinical populations, including GH-deficient [46], hemodialysis [55, 124], and metabolic syndrome [103, 111] patients. Regarding fitness/training level, 33 studies involved inactive untrained subjects, 23 studies involved mildly to moderately active subjects, and 24 studies involved welltrained athletes. The sample size was particularly variable from five to 524 participants, with $77.2 \%$ of studies involving less than 30 participants.

\subsection{Exercise Characteristics}

Among the 80 included studies, 51 studies investigated the ghrelin response to acute exercise, 28 studies examined the response to chronic exercise, and one study investigated the response to both acute and chronic exercise [79]. There was a high heterogeneity of studies in term of exercise/ training type, intensity, frequency, and duration. Several studies used more than one type, intensity, or duration of exercise. Acute exercise studies used either aerobic $(n=37)$, resistance $(n=6)$, intermittent $(n=7)$, or combined $(n=6)$ exercise. Regarding duration, 26, 14 and 11 studies used short-term ( $<60 \mathrm{~min}$ ), long-term ( $\geq 60 \mathrm{~min}$ ), and verylong term ( $\geq 90 \mathrm{~min}$ ) exercise, respectively. Chronic exercise studies used either aerobic $(n=17)$, resistance $(n=3)$, combined $(n=8)$, or intermittent $(n=1)$ training programs. Most of these studies $(n=20)$ applied a long-term program $(\geq 12$ weeks) whereas six and three studies used a shortterm ( $<12$ weeks) or very long-term ( $>48$ weeks) training program, respectively. In most acute or chronic exercise studies, the exercise was of moderate intensity. Some studies
Fig. 1 PRISMA (Preferred Reporting Items for Systematic reviews and Meta-Analysis) flow diagram of included studies

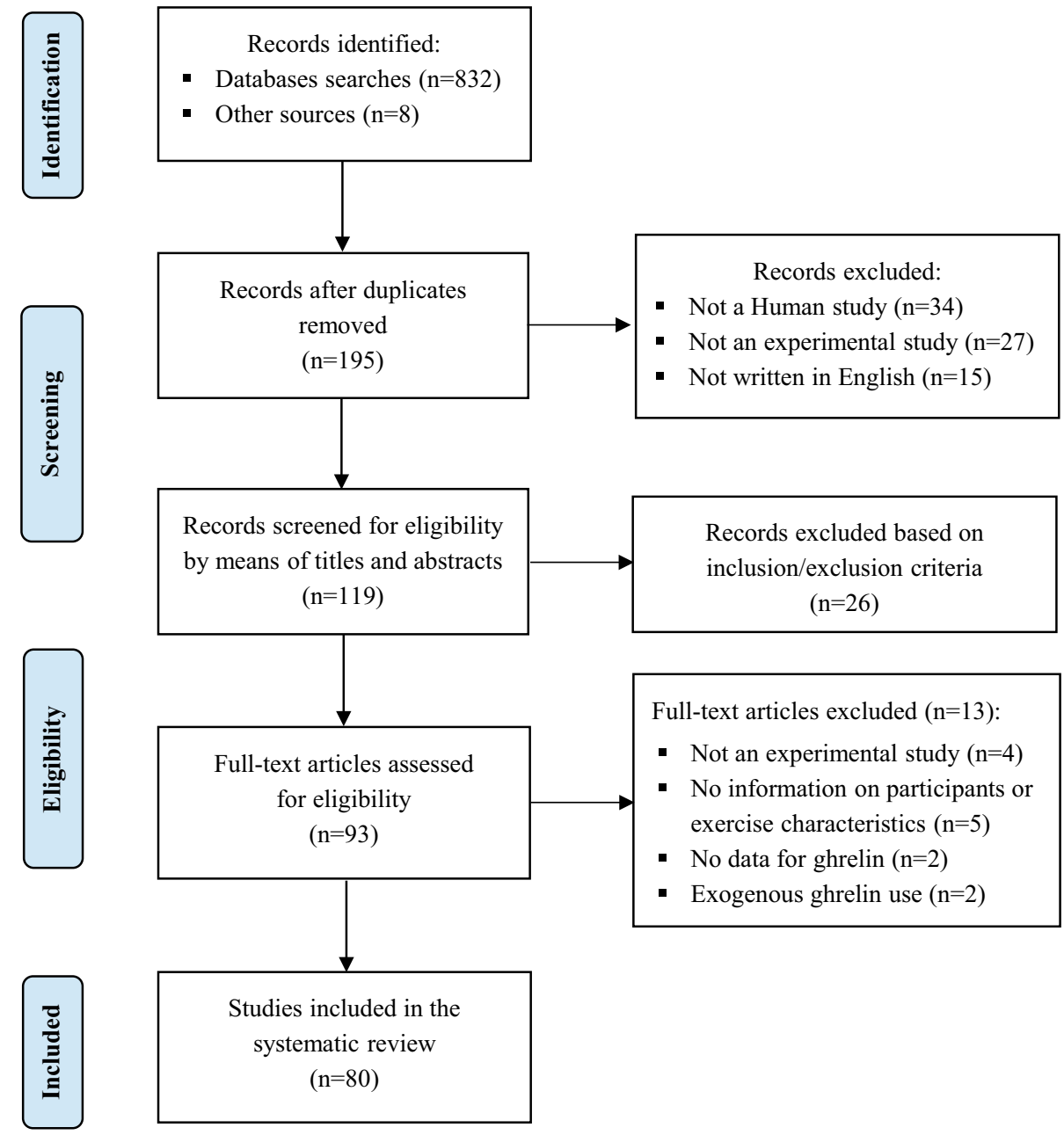




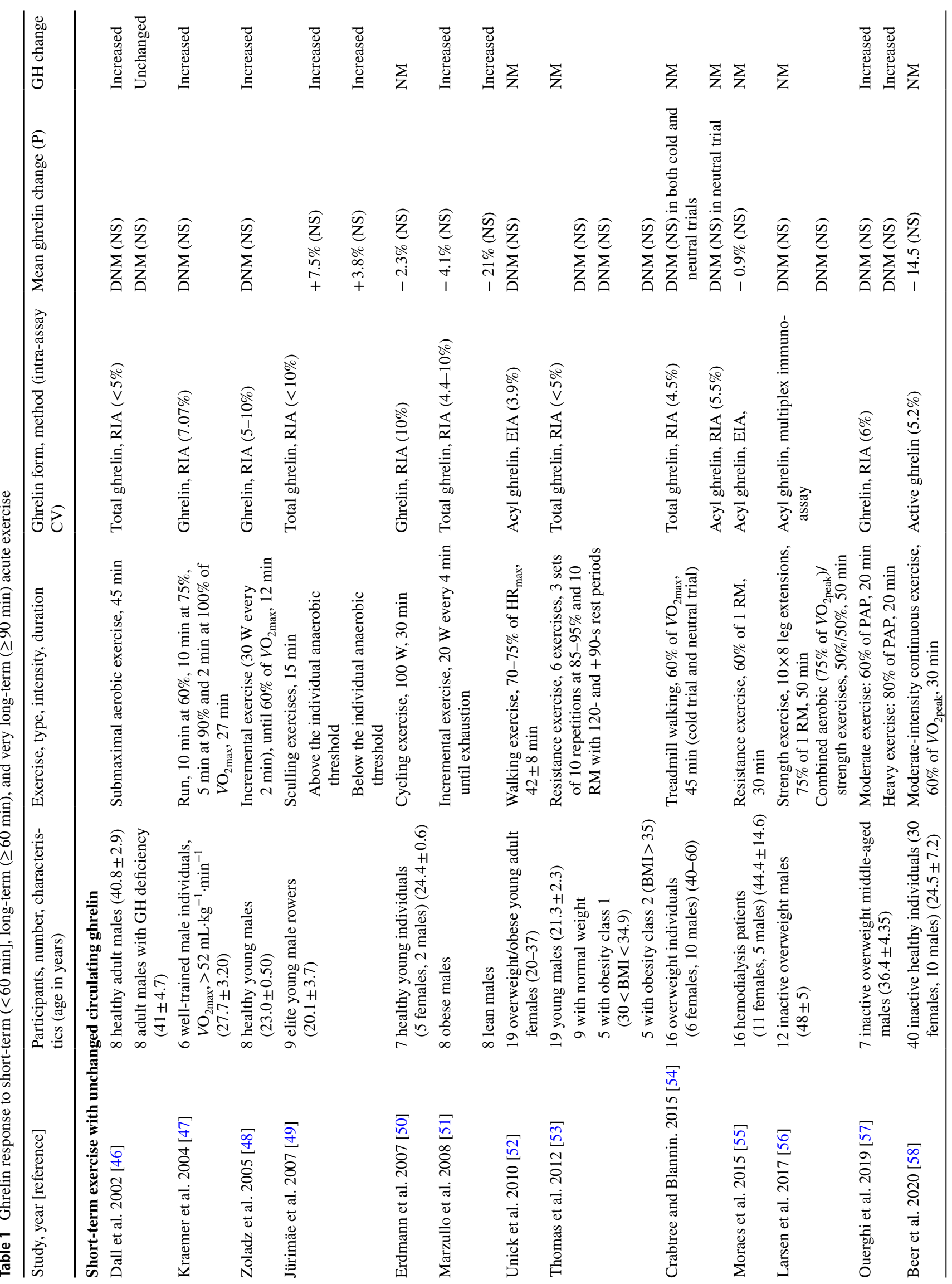




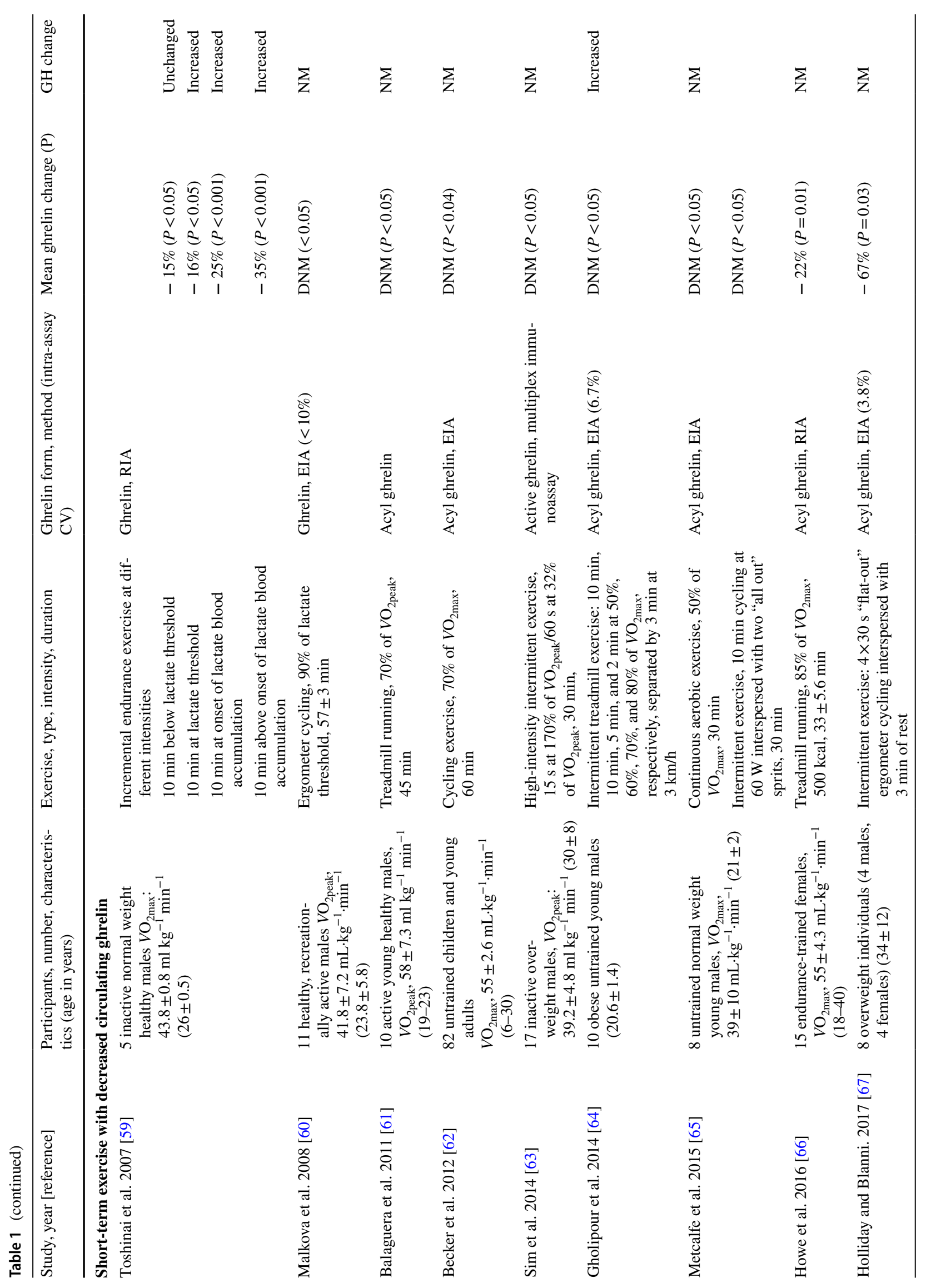




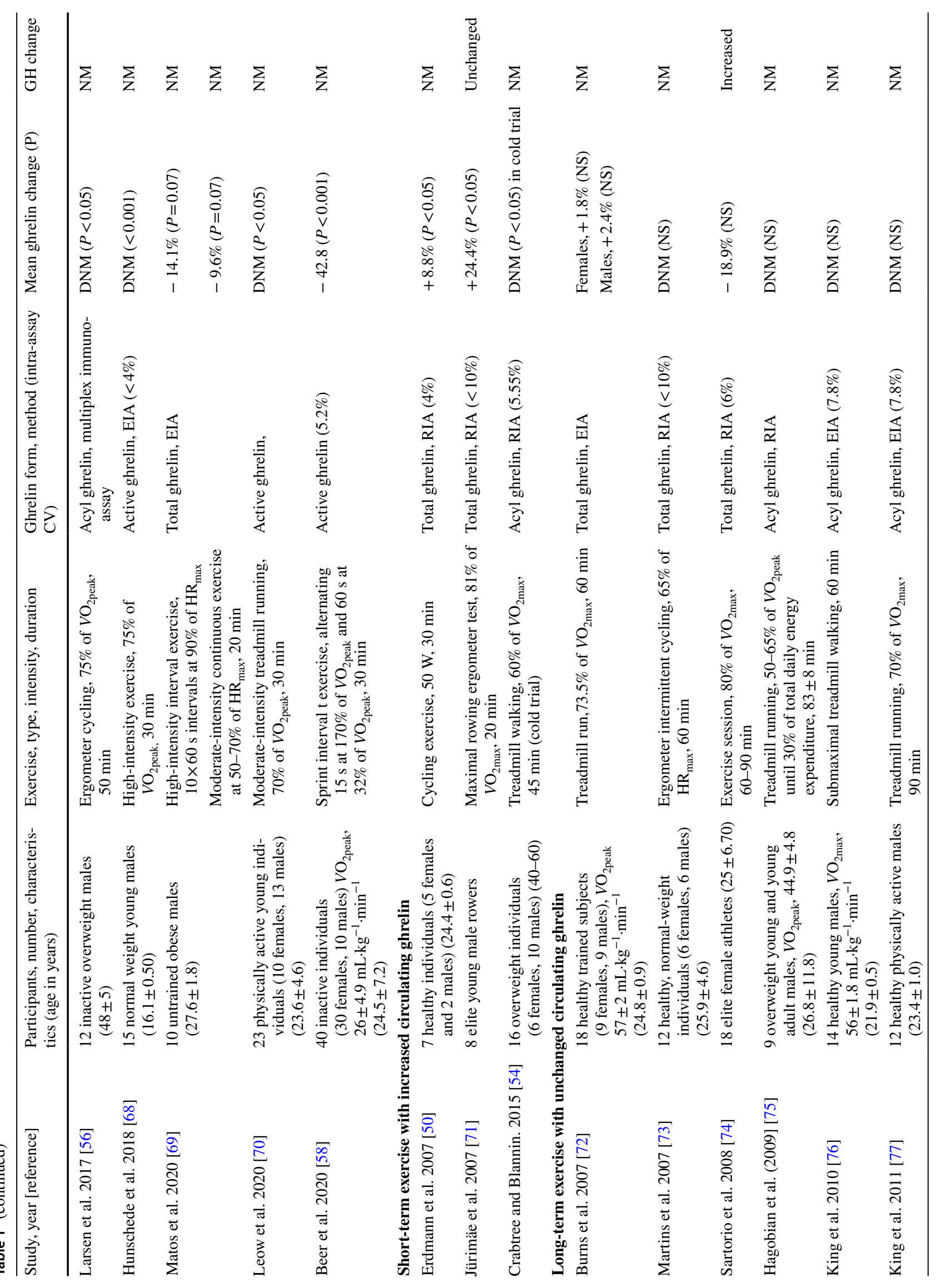




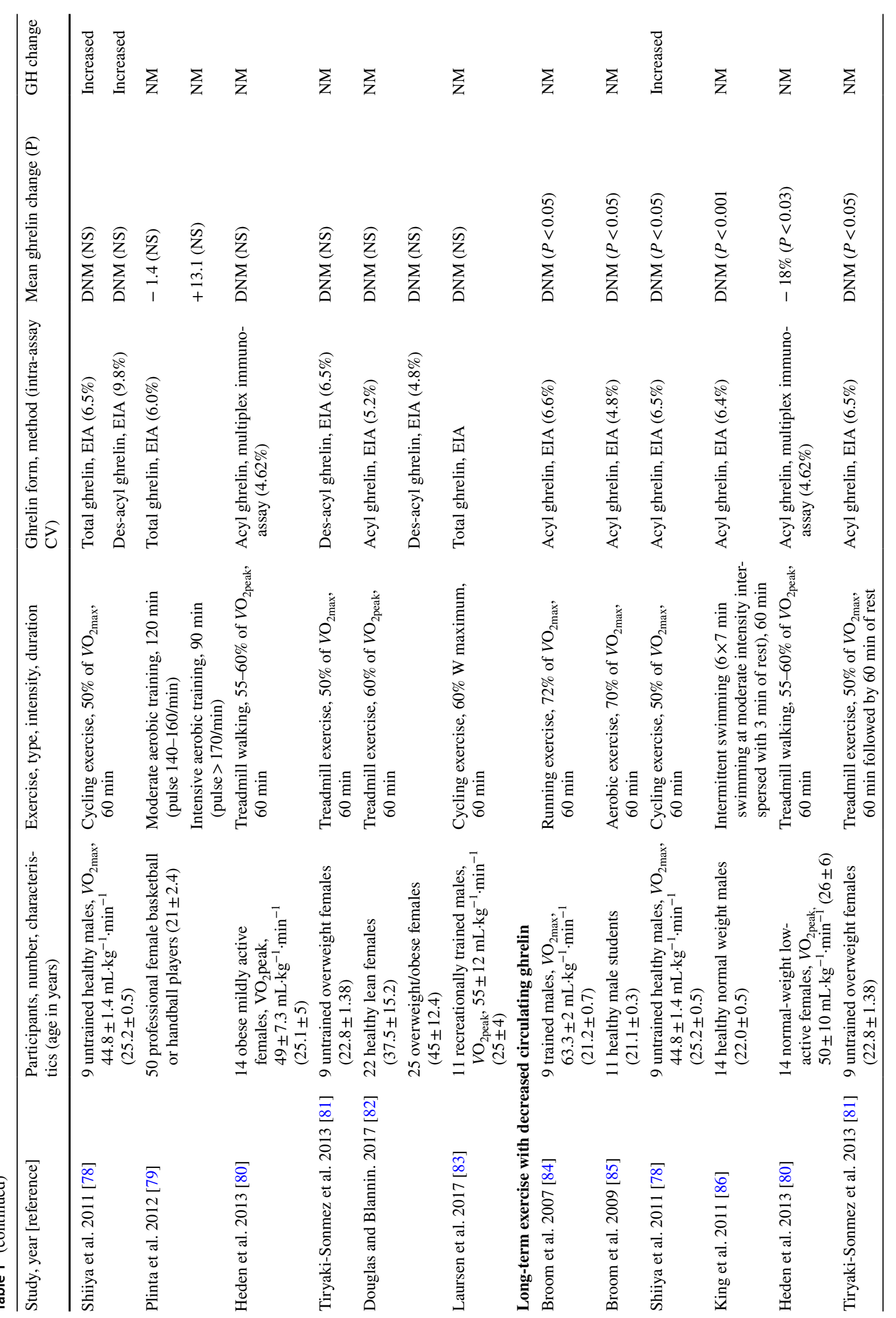




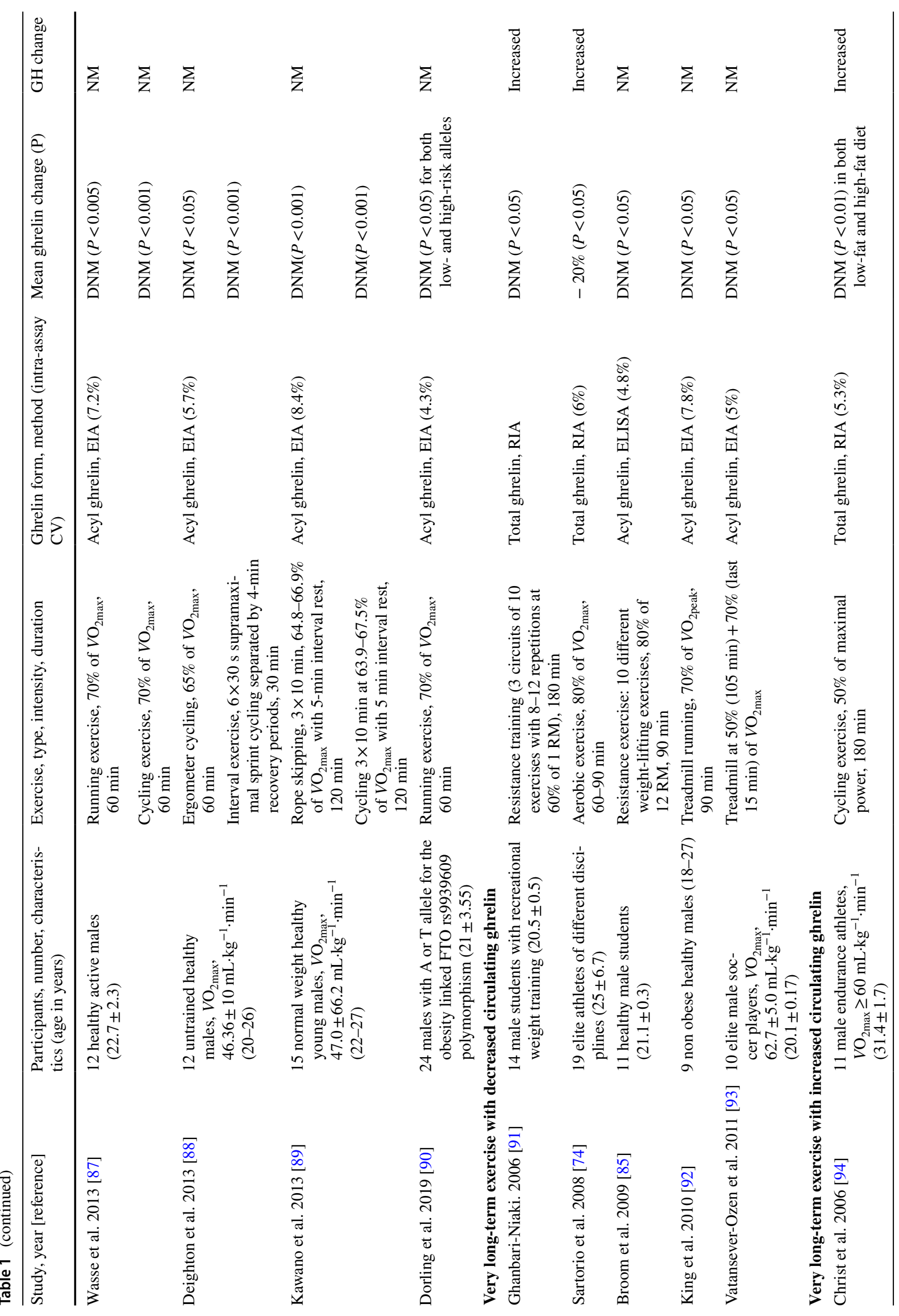




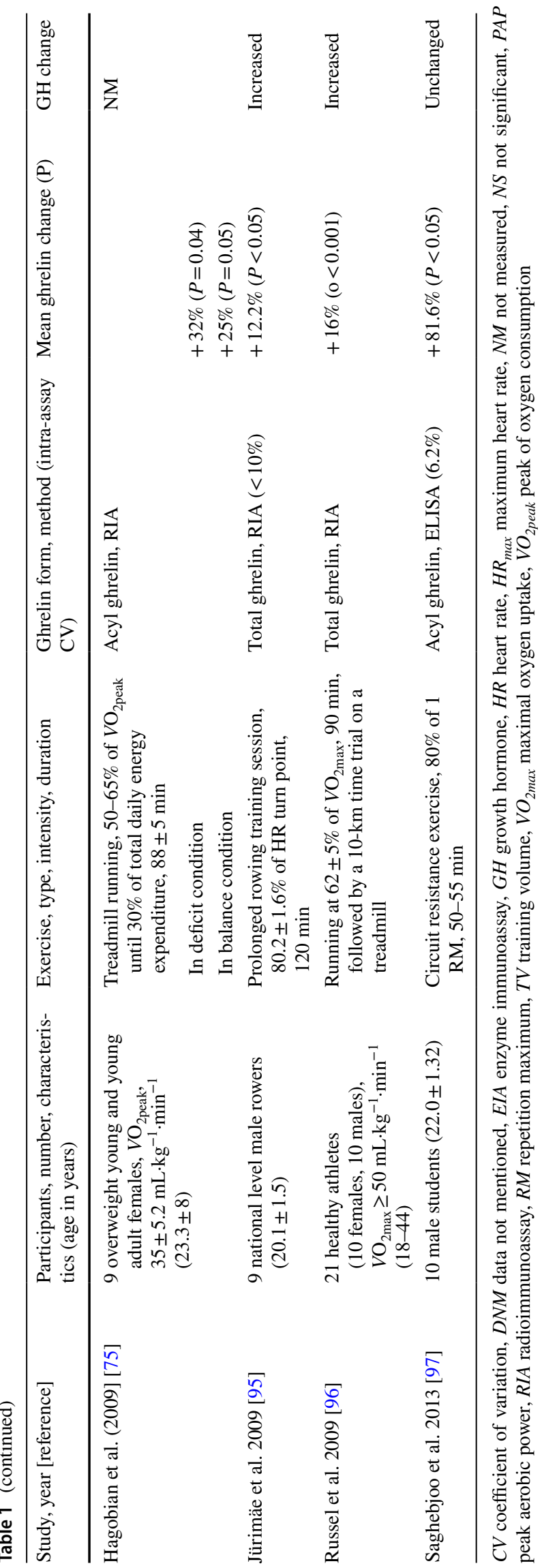

combined physical training with other interventions such as diet intervention $[104,122,123]$ or intragastric balloon placement [116].

\subsection{Analytical Characteristics}

Almost all studies measured one form of ghrelin while three studies measured more than one form [54, 78, 82]. Thirty-nine studies measured "total ghrelin (TG)/ghrelin", 37 studies measured "acyl/active ghrelin", and five studies measured DAG. In all studies, the measure was performed using high-quality immunoassay methods, generally with accurate precision.

\subsection{Response of Ghrelin According to Exercise Mode}

\subsubsection{Response to Acute Exercise}

Of the 25 studies that examined TG/ghrelin, most studies $(n=15)$ showed no change in circulating levels. These studies involved trained [47-50, 72-74, 79, 83] or untrained [46, $74]$, normal weight or overweight/obese [51, 53, 57] individuals, and one study involved both healthy subjects and GH-deficient patients [46]. A lack of ghrelin change was noted with short-term, long-term, or very long-term exercise of aerobic [46-51, 57, 69, 72, 74, 79, 83], resistance [53], combined [79], or intermittent [73] type. Five studies showed a decrease in trained [60,74, 91] or untrained [59], normal weight or overweight/obese [69] individuals following short- or long-term aerobic [60,74], resistance [91] or intermittent $[59,69]$ exercise. Finally, five studies involving active subjects showed an increase in TG following shortterm $[50,71]$ or very long-term [94-96] moderate-intensity aerobic exercise.

Thirty-six studies explored the effect of acute exercise by measuring AG. Most of these studies $(n=24)$ showed a significant decrease in circulating levels in participants with exercise of different types, intensities and durations [56, 58, $61-68,70,78,80,81,84-90,92,93]$. AG showed no significant change in nine studies involving either normal weight active individuals [58, 76, 77], inactive obese individuals $[52,56,80]$, both lean and obese subjects $[75,82]$ or hemodialysis patients [55] following aerobic [52, 58, 75-77, 80, 82], resistance [55], or combined [56] exercise. Finally, three studies in either healthy active or inactive obese individuals showed an increase in AG after moderate-intensity aerobic $[54,75]$ or high-intensity resistance [97] exercise.

Response of DAG to acute exercise was investigated in only three studies. All these studies showed no significant change in circulating levels following moderate-intensity aerobic exercise in healthy normal weight [78] and inactive overweight/obese [81, 82] young adults. Among 16 acute exercise studies that included a GH measurement, 13 studies 


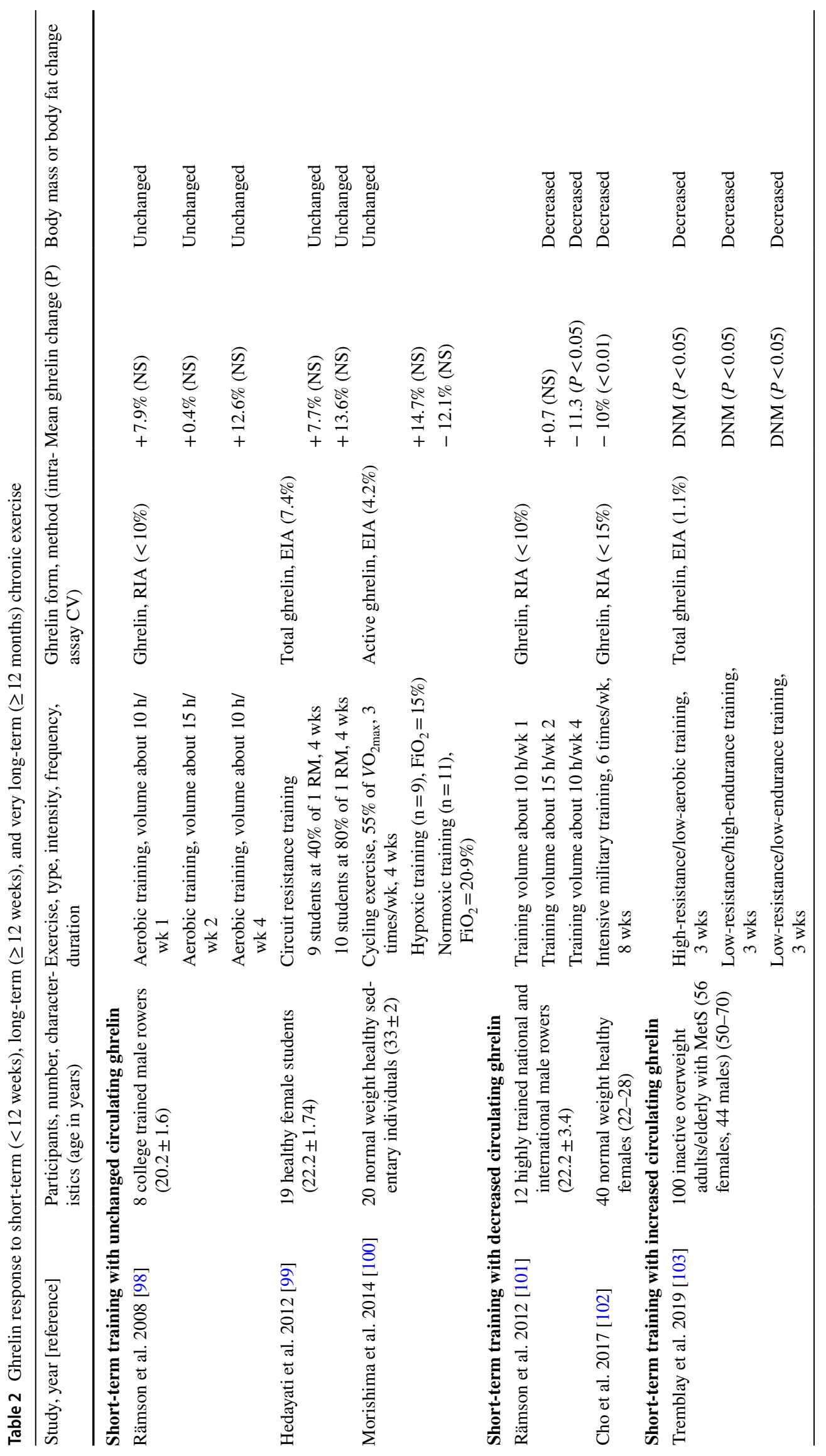




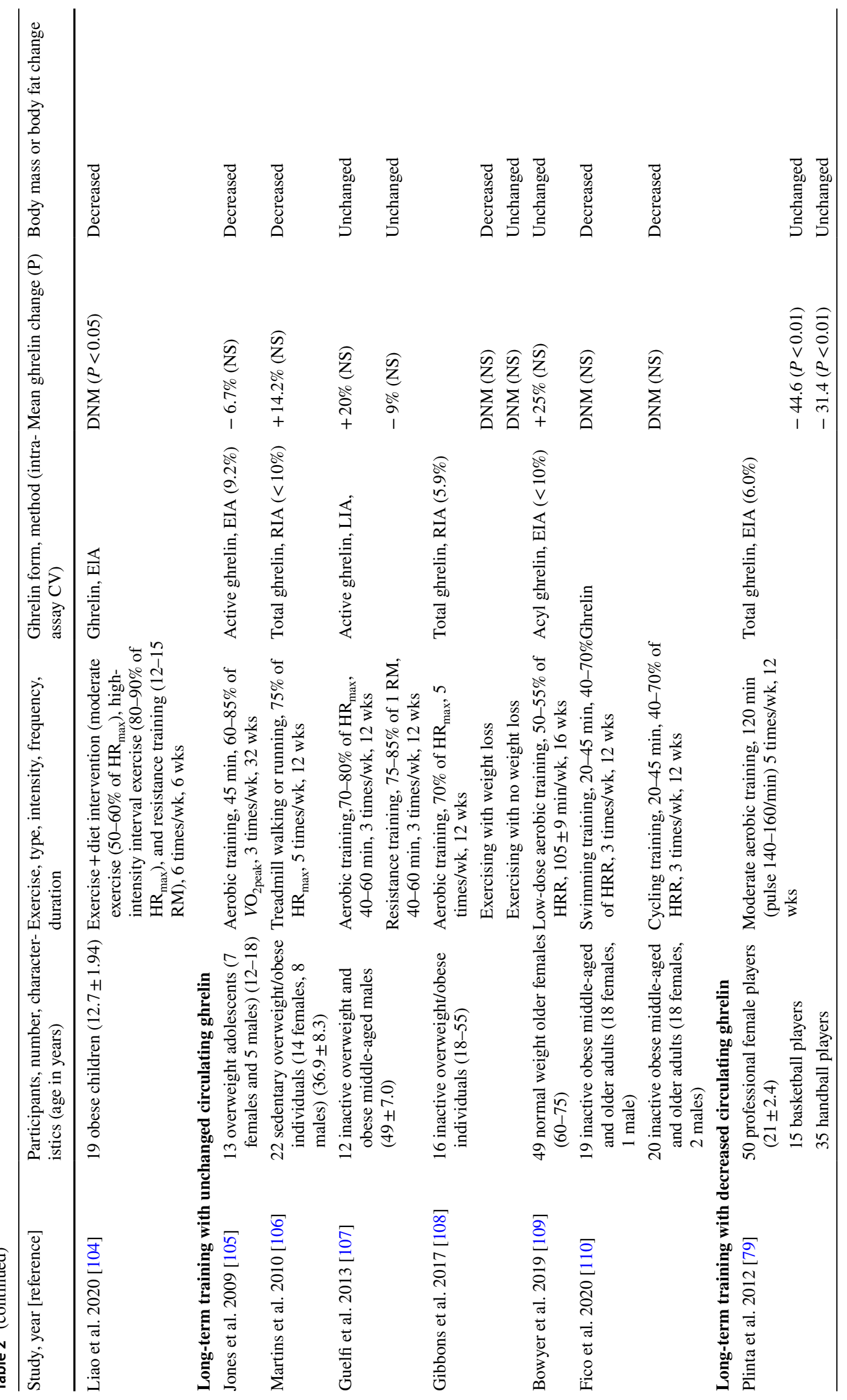




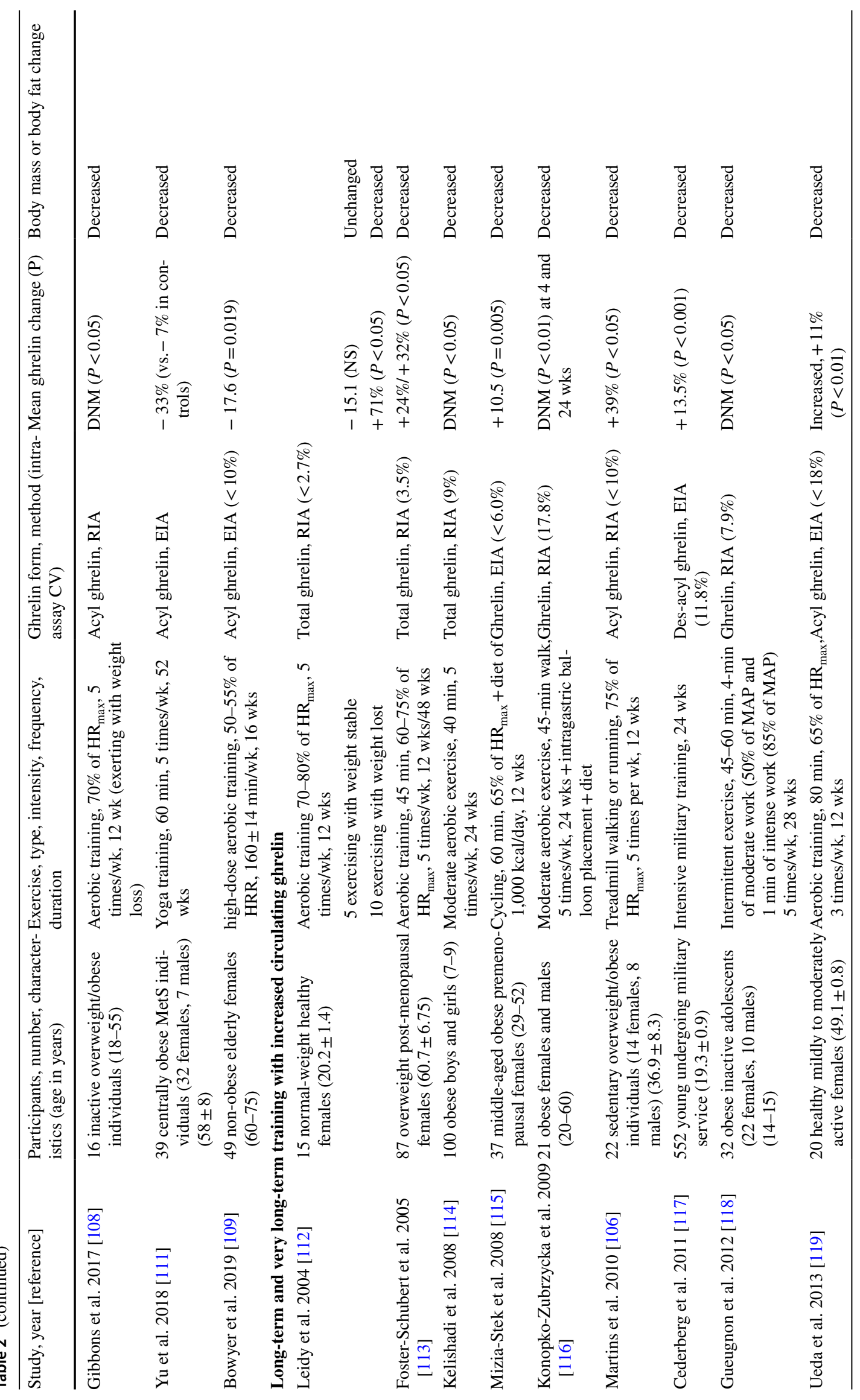




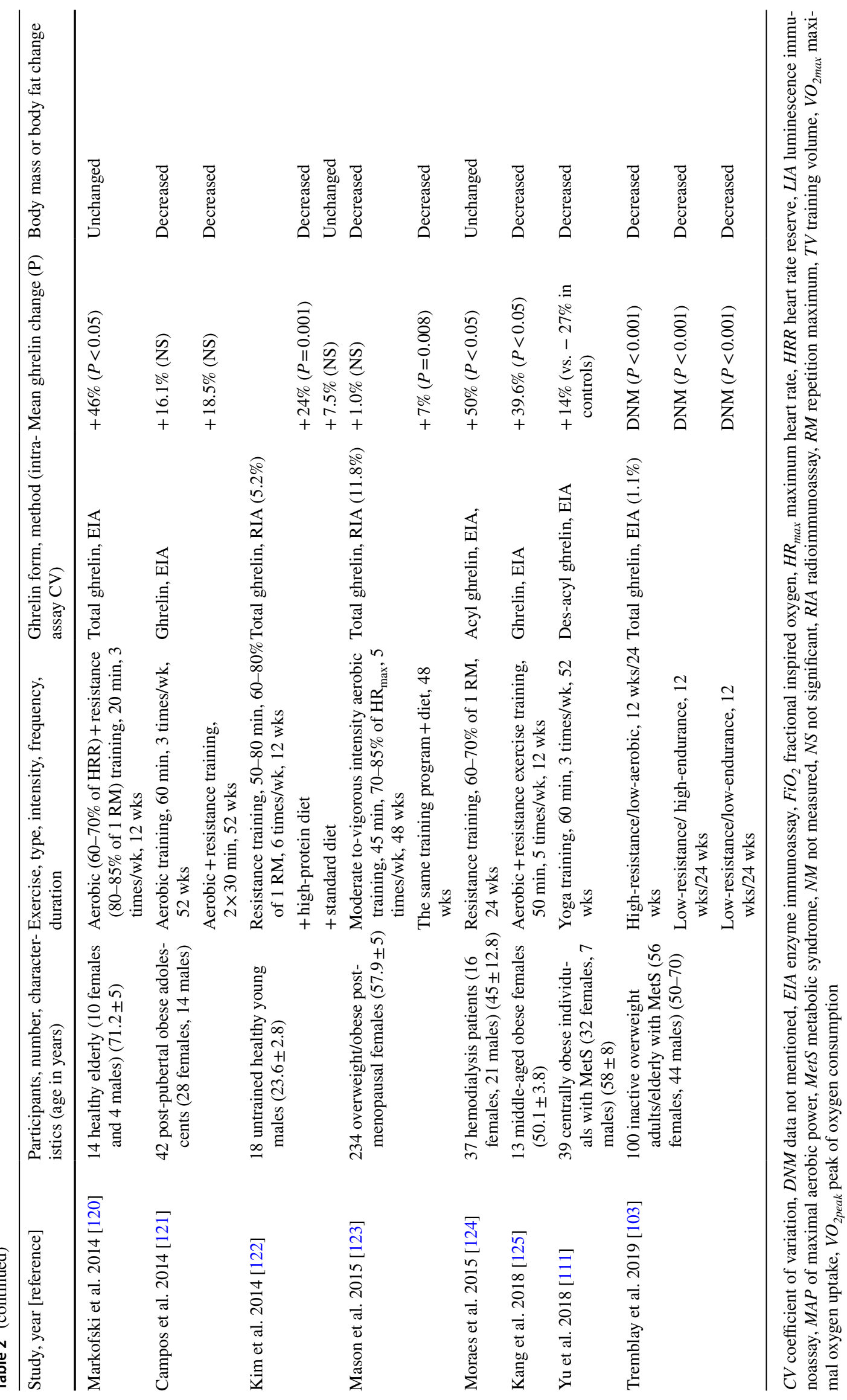


showed increased GH levels. However, three studies showed no variation in $\mathrm{GH}$ levels following acute exercise [46, 71, 97].

\subsubsection{Response to Chronic Exercise}

Of 21 chronic exercise studies that measured TG/ghrelin, two-thirds of studies showed an increase in circulating levels. The latter studies included children [104, 114], youth/ young adults [112, 118, 122], adults [115, 116, 121, 125], or seniors [103, 113, 120, 123], who were either active normal weight $[112,120,122]$ or inactive overweight/obese [103, 104, 113-116, 118, 121, 123, 125] individuals. The training was based on moderate- or high-intensity aerobic [112-116, 123], resistance [122], combined [103, 104, 120, 121, 125] or intermittent [118] exercise. An increase in ghrelin was mostly observed among physically inactive overweight/ obese rather than in normal weight individuals and with long-term than short-term training programs. Five studies showed no change in circulating TG in moderately [99] or highly trained [98] subjects or inactive obese subjects [106, $108,110]$ with aerobic $[98,106,108,110]$ or resistance [99] training programs of various durations. Finally, three studies involving well-trained young adults showed a decrease in TG levels following either short-term [101] or long-term [79] aerobic or short-term combined [102] exercise training.

AG was measured in ten studies using chronic exercise. Among these, three studies involving inactive or mildly active adults showed an increase in circulating levels following long-term moderate-intensity aerobic training [106, 119, 124]. Four studies showed no change in $A G$ in either normal weight $[100,109]$ or overweight/obese [105, 107] subjects who underwent short-term [100] or long-term [105, 107, 109] moderate-intensity aerobic training programs. Three studies involving active normal weight [109] or obese [108, 111] individuals showed a decrease in AG with long-term or very long-term $[108,109,111]$ moderate-intensity aerobic training.

Only two chronic exercise studies measured the deacylated form [111, 117]. DAG was significantly increased in active young adults undergoing a long-term combined training program [117], and in overweight/obese adults/ elderly participating in a very long-term moderate-intensity aerobic training (yoga exercise) [111]. In almost all chronic exercise studies $(n=27)$, the training program resulted in a significant decrease in body mass/fat. However, some studies showed no significant body composition change with the training program $[79,98-100,107,109,120,124]$.

\section{Discussion}

Despite numerous experimental and clinical data, the response of ghrelin to exercise has remained inconclusive. In this review, we summarized the currently available data aiming at advancing our knowledge on the topic. The search identified a high number of relevant studies $(n=80)$, which reported changes in circulating ghrelin levels with physical exercise as an outcome measure. The current review revealed large differences between studies in terms of participants' characteristics, exercise protocols, and measured ghrelin forms. This high variability led to a challenging interpretation of the outcomes. Data were inconsistent, with reports showing increased, decreased, or unchanged circulating ghrelin levels with acute or chronic exercise. Since previous research revealed different responses with ghrelin to acute and chronic exercise and distinct physiological actions and possibly regulation pathways of ghrelin isoforms (i.e., AG and DAG) [3, 11-13, 42-44], the changes were examined by exercise modality (acute or chronic) and ghrelin isoform (AG, DAG or TG).

Among acute exercise studies, more than two-thirds of the studies measuring TG showed no significant change in circulating levels. However, AG levels were significantly decreased in $80 \%$ of the studies detecting this form. The suppression of AG was thought to be transient [76-78, 84, 85], but a recent powered analysis of pooled data demonstrated that acute exercise robustly suppresses circulating AG, which remains suppressed for several hours beyond the end of exercise [126]. The mechanisms underlining the exercise-induced suppression or stability of ghrelin are unclear. They reflect processes interfering with ghrelin synthesis via the modulation of GOAT or esterase activities or with its secretion into the circulation [127-129]. AG might decrease in response to augmented sympathetic output and/or gastric mucosal ischemia resulting from redistribution of blood flow from the splanchnic circulation towards the skeletal muscles during exercise [130]. It was also suggested that exerciseinduced GH secretion exerts negative feedback on ghrelin production [42]. Most included studies reporting AG suppression did not include GH measurement. Only two of these studies showed an increase in GH following acute exercise $[64,78]$. Further research is needed to further clarify these mechanisms.

Overall, despite discrepancies between the studies, the current review suggests that acute exercise suppresses AG while not altering TG production. However, no clear relationship has emerged between ghrelin changes, whatever the form measured, and age class, body composition, and physical aptitude of participants as well as exercise type, intensity, and duration. These findings disagree with previous studies and reviews suggesting that exercise intensity 
might influence AG production $[44,63,65,76,77,88]$. The physiological relevance of AG suppression is uncertain. Although AG is proven to stimulate appetite and energy intake, changes in circulating AG with exercise were not strongly linked to changes in energy intake [84, 88, 92]. Other physiological or psychological factors likely have a greater effect on energy intake/food preference [44].

The review provided evidence that chronic exercise increases circulating TG and DAG production. Up to threequarters of long-term training program studies showed an increase in circulating TG levels. A change in DAG following chronic exercise programs was rarely explored. The two studies that measured this isoform showed increased circulating levels with a long-term training program [111, 117]. The increases occurred especially in inactive overweight/obese people. Unlike TG and DAG, circulating AG levels were often unchanged or decreased. Assuming that DAG is the predominant form of ghrelin [3-5], with most studies showing no change in AG with chronic exercise, the increase in TG likely relates to the deacylated isoform. Yu et al. [117] examined the effects of a 1-year program of aerobic exercise training on both isoforms in obese subjects with metabolic syndrome. The program resulted in weight loss with an increase in DAG levels ( $+14 \%$ vs. $-27 \%$ in controls) while AG was significantly suppressed ( $-33 \%$ vs. $-7 \%$ in controls).

The increase in TG/DAG associated with training programs was generally associated with weight loss $[103,104$, $111,113-118,121,123,125]$. So, whether the increase results from weight loss or from exercise per se is uncertain. However, TG levels were not increased when the training programs resulted in no weight loss [98-100, 107, 109]. Moreover, ghrelin levels changes are tightly correlated with changes in body mass/body fat $[112,113]$, which suggests that increases in TG or DAG are likely due to weight loss. In support of this hypothesis, the increases have been mostly seen in overweight/obese individuals and following long-term training programs. Weight loss is indeed more likely to occur in obese than normal weight people and in long-term rather than short-term training programs. Interestingly, Leidy et al. [112], Foster-Schubert et al. [113], and Kim et al. [122], investigating the combined effects of chronic exercise and diet, showed that TG levels only increase in participants who experienced significant weight loss. Conversely, training without significant weight loss has no impact on TG. However, other chronic exercise studies reported unchanged [108, 120, 121] or decreased [101, 102] circulating TG levels despite weight loss occurring. How changes in body mass/fat impact on circulating ghrelin is not fully understood. The changes might be due to alterations in leptin and insulin metabolism associated with weight loss. Since leptin exerts an inhibitory effect on ghrelin production [131], weight loss-induced decrease in leptin secretion results in increased ghrelin production. Accordingly, ghrelin was found to negatively correlate with leptin [132] and insulin resistance [133].

The current review failed to identify groups of individuals or types of exercise that are specifically associated with changes in circulating ghrelin. However, it suggests that prolonged high-intensity acute exercise is more effective in suppressing AG. Such exercise induces a sharper increase in sympathetic output and a more pronounced splanchnic ischemia. The review also provided evidence that long-term training is prone to increase total and des-acyl ghrelin production in overweight/obese people. This form of chronic exercise is more efficient in reducing body mass/fat, especially in obese people.

The two isoforms of ghrelin were proven to exert opposing effects on glucose and lipid metabolism and to contrarily correlate with body mass/fat $[11,13]$. AG suppresses insulin secretion and stimulates glucose output from hepatocytes, while DAG exerts the opposite effects $[18,21,22]$, and promotes $\beta$-cell survival and improves insulin sensitivity $[30,31]$. Furthermore, obesity is associated with decreased levels of DAG and increased or normal levels of AG [20, 32]. Accordingly, high circulating AG levels are supposed to reflect increased metabolic risk, while high DAG levels and a low AG:DAG ratio would reflect low metabolic risk. Therefore, observed changes in circulating ghrelin, i.e., decrease in AG with acute exercise and increase in TG/DAG with long-term training, could be regarded as metabolically beneficial.

The current review included numerous studies covering existing literature and current knowledge in the field. This abundance of literature can be regarded as a strength since it would elicit an advance in the understanding of the impact of physical exercise on ghrelin pathways. Nevertheless, the high variability of the studies in terms of participants and exercise characteristics and ghrelin isoforms led to inconsistent results, making it difficult to draw firm conclusions. Studies involved children, youths, adults, or seniors who were either healthy normal weight or overweight/obese individuals or ill patients. Participants were physically inactive, mildly to moderately active, or highly-trained athletes. Physical intervention consisted of aerobic, resistance, intermittent, or combined exercise, of moderate- or high-intensity and variable durations. In some studies, physical exercise was combined with another intervention, especially diet. Another important source of variability was the impact of food intake on ghrelin levels. Participants exercised either in fasted or fed states with pre-exercise meals varying in caloric content, macronutrient composition, and the time at which they were provided. Diverse combinations of these factors and differences in body composition, food intake, sample collection/processing, timing of blood draw versus eating and exercising, and assay procedure may have influenced 
the results, making it difficult to compare outcomes of different studies.

By increasing permeability and hydrostatic pressure, acute exercise induces shifts of plasma water to the extravascular space. This causes false changes in ghrelin levels, which could confound the specific effect of exercise. Several studies in this review did not adjust for plasma volume shifts, which could have prevented an accurate estimate of ghrelin change. Since plasma shift normally causes an increase, not a decrease, in levels, AG decrease in most acute exercise studies is likely independent of these changes. Some studies did not implement a non-exercise control group, making it impossible to determine whether outcomes were solely related to exercise. Finally, small sample sizes in several studies and large between-individual variation in ghrelin levels may have underpowered some studies and prevented recognition of significant effects.

Unlike previous reviews, the current review is systematic, exhaustive, and not selective. It offers a comprehensive upto-date view on the topic. Although the findings broadly agree with previous reviews, the review does present some novelties. It establishes that AG suppression persists beyond the end of acute exercise and is independent of exercise intensity, contrary to what has been assumed previously. It claims that increases in TG and DAG with chronic exercise are more noticeable in overweight/obese people and wih long-term programs. Novelties include the response of DAG to exercise, which was proven to increase with chronic but not acute exercise. Finally, the review findings allowed prediction of potentially beneficial ghrelin changes.

\section{Conclusions}

The present review revealed a high variability in studies in terms of participants and exercise characteristics, as well as other factors, such as food intake, that could affect ghrelin level outcomes. This makes it challenging to interpret the data. However, the review provides evidence that acute exercise suppresses AG regardless of participants and exercise characteristics. The suppression, initially considered as transient, seems to persist beyond the end of exercise. The mechanisms responsible for the change remain hypothetical. Their relevance is unclear since the effect on appetite and energy intake seems to be absent or modest. The review suggests that chronic exercise is rather associated with increased production of TG and DAG, especially with prolonged exercise training programs and among overweight/obese individuals. These changes are likely due to weight loss rather than exercise per se. Predominant ghrelin changes (i.e., decreased AG and increased TG/DAG) are expected to reduce metabolic risk since they are supposed to reduce energy intake and fat accumulation, and enhance insulin secretion and sensitivity.
Nevertheless, the results should be considered with caution given a great variability in the literature data and methodological limitations in some studies. Further research is needed for a better understanding of the effects of physical exercise on ghrelin production and metabolism. Future well-controlled trials should involve homogeneous groups of participants and use well-defined physical interventions while measuring the two isoforms of ghrelin.

\section{Declarations}

Funding Open Access funding provided by Universität Zürich. No sources of funding were used to assist in the preparation of this article.

Conflict of interest Nejmeddine Ouerghi, Moncef Feki, Nicola Bragazzi, Beat Knechtle, Lee Hill, Pantelis Nikolaidis, and Anissa Bouassida declare that they have no conflicts of interest relevant to the content of this review.

Data availability statement Data sharing is not applicable to this article as no datasets were generated during the current study.

Author contributions $\mathrm{NO}, \mathrm{MF}$, and $\mathrm{AB}$ conceived the article. NO, MF, and $\mathrm{AB}$ conducted the literature search and wrote the manuscript draft. LH, PTN, and BK reviewed and helped in drafting the final manuscript. All authors critically revised and contributed to the manuscript. All authors read and approved the final manuscript.

Open Access This article is licensed under a Creative Commons Attribution 4.0 International License, which permits use, sharing, adaptation, distribution and reproduction in any medium or format, as long as you give appropriate credit to the original author(s) and the source, provide a link to the Creative Commons licence, and indicate if changes were made. The images or other third party material in this article are included in the article's Creative Commons licence, unless indicated otherwise in a credit line to the material. If material is not included in the article's Creative Commons licence and your intended use is not permitted by statutory regulation or exceeds the permitted use, you will need to obtain permission directly from the copyright holder. To view a copy of this licence, visit http://creativecommons.org/licenses/by/4.0/.

\section{References}

1. Stengel A, Taché Y. Ghrelin-a pleiotropic hormone secreted from endocrine x/a-like cells of the stomach. Front Neurosci. 2012;6:24. https://doi.org/10.3389/fnins.2012.00024.

2. Kojima M, Hosoda H, Date Y, Nakazato M, Matsuo H, Kangawa $\mathrm{K}$. Ghrelin is a growth-hormone-releasing acylated peptide from stomach. Nature. 1999;402(6762):656-60. https://doi.org/ $10.1038 / 45230$.

3. Liu J, Prudom CE, Nass R, Pezzoli SS, Oliveri MC, Johnson $\mathrm{ML}$, et al. Novel ghrelin assays provide evidence for independent regulation of ghrelin acylation and secretion in healthy young men. J Clin Endocrinol Metab. 2008;93(5):1980-7. https://doi. org/10.1210/jc.2007-2235.

4. Tong J, Dave N, Mugundu GM, Davis HW, Gaylinn BD, Thorner MO, et al. The pharmacokinetics of acyl, des-acyl, and total ghrelin in healthy human subjects. Eur J Endocrinol. 2013;168(6):821-8. https://doi.org/10.1530/EJE-13-0072. 
5. Psichas A, Reimann F, Gribble FM. Gut chemosensing mechanisms. J Clin Investig. 2015;125(3):908-17. https://doi.org/10. 1172/JCI76309.

6. Gutierrez JA, Solenberg PJ, Perkins DR, Willency JA, Knierman $\mathrm{MD}$, Jin Z, et al. Ghrelin octanoylation mediated by an orphan lipid transferase. Proc Natl Acad Sci USA. 2008;105(17):6320-5. https://doi.org/10.1073/pnas.0800708105.

7. Goebel-Stengel M, Hofmann T, Elbelt U, Teuffel P, Ahnis A, Kobelt $\mathrm{P}$, et al. The ghrelin activating enzyme ghrelin-O-acyltransferase (GOAT) is present in human plasma and expressed dependent on body mass index. Peptides. 2013;43:13-9. https:// doi.org/10.1016/j.peptides.2013.02.011.

8. Murtuza MI, Isokawa M. Endogenous ghrelin- $O$-acyltransferase (GOAT) acylates local ghrelin in the hippocampus. J Neurochem. 2018;144(1):58-67. https://doi.org/10.1111/jnc.14244.

9. Yanagi S, Sato T, Kangawa K, Nakazato M. The homeostatic force of ghrelin. Cell Metab. 2018;27(4):786-804. https://doi. org/10.1016/j.cmet.2018.02.008.

10. Gauna C, Kiewiet RM, Janssen JA, van de Zande B, Delhanty PJ, Ghigo E, et al. Unacylated ghrelin acts as a potent insulin secretagogue in glucose-stimulated conditions. Am J Physiol Endocrinol Metab. 2007;293(3):E697-704. https://doi.org/10.1152/ajpendo. 00219.2007.

11. Delhanty PJ, Neggers SJ, van der Lely AJ. Mechanisms in endocrinology: ghrelin: the differences between acyl- and des-acyl ghrelin. Eur J Endocrinol. 2012;167(5):601-8. https://doi.org/ 10.1530/EJE-12-0456.

12. Asakawa A, Inui A, Fujimiya M, Sakamaki R, Shinfuku N, Ueta $\mathrm{Y}$, et al. Stomach regulates energy balance via acylated ghrelin and desacyl ghrelin. Gut. 2005;54(1):18-24. https://doi.org/10. 1136/gut.2004.038737.

13. Delhanty PJ, Neggers SJ, van der Lely AJ. Should we consider des-acyl ghrelin as a separate hormone and if so, what does it do? Front Horm Res. 2014;42:163-74. https://doi.org/10.1159/ 000358345 .

14. Masuda $\mathrm{Y}$, Tanaka $\mathrm{T}$, Inomata $\mathrm{N}$, Ohnuma $\mathrm{N}$, Tanaka $\mathrm{S}$, Itoh $\mathrm{Z}$, et al. Ghrelin stimulates gastric acid secretion and motility in rats. Biochem Biophys Res Commun. 2000;276(3):905-8. https://doi.org/10.1006/bbrc.2000.3568.

15. Shi L, Du X, Jiang H, Xie J. Ghrelin and neurodegenerative disorders-a review. Mol Neurobiol. 2017;54(2):1144-55. https://doi. org/10.1007/s12035-016-9729-1.

16. Tong J, Prigeon RL, Davis HW, Bidlingmaier M, Kahn SE, Cummings DE, et al. Ghrelin suppresses glucose-stimulated insulin secretion and deteriorates glucose tolerance in healthy humans. Diabetes. 2010;59(9):2145-51. https://doi.org/10.2337/ db10-0504.

17. Dezaki K, Hosoda H, Kakei M, Hashiguchi S, Watanabe M, Kangawa K, et al. Endogenous ghrelin in pancreatic islets restricts insulin release by attenuating $\mathrm{Ca}^{2+}$ signaling in betacells: implication in the glycemic control in rodents. Diabetes. 2004;53(12):3142-51. https://doi.org/10.2337/diabetes.53.12. 3142.

18. Gauna C, Meyler FM, Janssen JA, Delhanty PJ, Abribat T, van Koetsveld P, et al. Administration of acylated ghrelin reduces insulin sensitivity, whereas the combination of acylated plus unacylated ghrelin strongly improves insulin sensitivity. J Clin Endocrinol Metab. 2004;89(10):5035-42. https://doi.org/10. 1210/jc.2004-0363.

19. Vestergaard ET, Djurhuus CB, Gjedsted J, Nielsen S, Møller N, Holst JJ, et al. Acute effects of ghrelin administration on glucose and lipid metabolism. J Clin Endocrinol Metab. 2008;93(2):43844. https://doi.org/10.1210/jc.2007-2018.

20. Barazzoni R, Zanetti M, Ferreira C, Vinci P, Pirulli A, Mucci $\mathrm{M}$, et al. Relationships between desacylated and acylated ghrelin and insulin sensitivity in the metabolic syndrome. J Clin
Endocrinol Metab. 2007;92(10):3935-40. https://doi.org/10. 1210/jc.2006-2527.

21. Gauna C, Delhanty PJ, Hofland LJ, Janssen JA, Broglio F, Ross RJ, et al. Ghrelin stimulates, whereas des-octanoyl ghrelin inhibits, glucose output by primary hepatocytes. J Clin Endocrinol Metab. 2005;90(2):1055-60. https://doi.org/10.1210/jc. 2004-1069.

22. Dezaki K, Sone H, Koizumi M, Nakata M, Kakei M, Nagai $\mathrm{H}$, et al. Blockade of pancreatic islet-derived ghrelin enhances insulin secretion to prevent high-fat diet-induced glucose intolerance. Diabetes. 2006;55(12):3486-93. https://doi.org/10.2337/ db06-0878.

23. Sun Y, Asnicar M, Saha PK, Chan L, Smith RG. Ablation of ghrelin improves the diabetic but not obese phenotype of ob/ob mice. Cell Metab. 2006;3(5):379-86. https://doi.org/10.1016/j. cmet.2006.04.004.

24. Esler WP, Rudolph J, Claus TH, Tang W, Barucci N, Brown SE, et al. Small-molecule ghrelin receptor antagonists improve glucose tolerance, suppress appetite, and promote weight loss. Endocrinology. 2007;148(11):5175-85. https://doi.org/10.1210/ en.2007-0239.

25. Brial F, Lussier CR, Belleville K, Sarret P, Boudreau F. Ghrelin inhibition restores glucose homeostasis in hepatocyte nuclear factor-1 $\alpha$ (MODY3)-deficient mice. Diabetes. 2015;64(9):3314 20. https://doi.org/10.2337/db15-0124.

26. Theander-Carrillo C, Wiedmer P, Cettour-Rose P, Nogueiras R, Perez-Tilve D, Pfluger P, et al. Ghrelin action in the brain controls adipocyte metabolism. J Clin Investig. 2006;116(7):1983-93. https://doi.org/10.1172/JCI25811.

27. Davies JS, Kotokorpi P, Eccles SR, Barnes SK, Tokarczuk PF, Allen SK, et al. Ghrelin induces abdominal obesity via GHS-Rdependent lipid retention. Mol Endocrinol. 2009;23(6):914-24. https://doi.org/10.1210/me.2008-0432.

28. Lin L, Saha PK, Ma X, Henshaw IO, Shao L, Chang BH, et al. Ablation of ghrelin receptor reduces adiposity and improves insulin sensitivity during aging by regulating fat metabolism in white and brown adipose tissues. Aging Cell. 2011;10(6):996-1010. https://doi.org/10.1111/j.1474-9726.2011.00740.x.

29. Granata R, Settanni F, Biancone L, Trovato L, Nano R, Bertuzzi F, et al. Acylated and unacylated ghrelin promote proliferation and inhibit apoptosis of pancreatic beta-cells and human islets: involvement of 3',5'-cyclic adenosine monophosphate/ protein kinase A, extracellular signal-regulated kinase 1/2, and phosphatidyl inositol 3-Kinase/Akt signaling. Endocrinology. 2007;148(2):512-29. https://doi.org/10.1210/en.2006-0266.

30. Cederberg H, Koivisto VM, Jokelainen J, Surcel HM, KeinänenKiukaanniemi S, Rajala U. Unacylated ghrelin is associated with changes in insulin sensitivity and lipid profile during an exercise intervention. Clin Endocrinol (Oxf). 2012;76(1):39-45. https:// doi.org/10.1111/j.1365-2265.2011.04135.x.

31. Granata R, Settanni F, Julien M, Nano R, Togliatto G, Trombetta A, et al. Des-acyl ghrelin fragments and analogues promote survival of pancreatic $\beta$-cells and human pancreatic islets and prevent diabetes in streptozotocin-treated rats. J Med Chem. 2012;55(6):2585-96. https://doi.org/10.1021/jm201223m.

32. Rodríguez A, Gómez-Ambrosi J, Catalán V, Gil MJ, Becerril $\mathrm{S}$, Sáinz N, et al. Acylated and desacyl ghrelin stimulate lipid accumulation in human visceral adipocytes. Int J Obes (Lond). 2009;33(5):541-52. https://doi.org/10.1038/ijo.2009.40.

33. Lear PV, Iglesias MJ, Feijóo-Bandín S, Rodríguez-Penas D, Mosquera-Leal A, García-Rúa V, et al. Des-acyl ghrelin has specific binding sites and different metabolic effects from ghrelin in cardiomyocytes. Endocrinology. 2010;151(7):3286-98. https:// doi.org/10.1210/en.2009-1205.

34. Shiiya T, Nakazato M, Mizuta M, Date Y, Mondal MS, Tanaka $\mathrm{M}$, et al. Plasma ghrelin levels in lean and obese humans and the 
effect of glucose on ghrelin secretion. J Clin Endocrinol Metab. 2002;87(1):240-4. https://doi.org/10.1210/jcem.87.1.8129.

35. Sakata I, Park WM, Walker AK, Piper PK, Chuang JC, OsborneLawrence $\mathrm{S}$, et al. Glucose-mediated control of ghrelin release from primary cultures of gastric mucosal cells. Am J Physiol Endocrinol Metab. 2012;302(10):E1300-10. https://doi.org/10. 1152/ajpendo.00041.2012.

36. Vancleef L, Van Den Broeck T, Thijs T, Steensels S, Briand L, Tack J, et al. Chemosensory signalling pathways involved in sensing of amino acids by the ghrelin cell. Sci Rep. 2015;5:15725. https://doi.org/10.1038/srep15725.

37. Mundinger TO, Cummings DE, Taborsky GJ Jr. Direct stimulation of ghrelin secretion by sympathetic nerves. Endocrinology. 2006;147(6):2893-901. https://doi.org/10.1210/en.2005-1182.

38. Hosoda H, Kangawa K. The autonomic nervous system regulates gastric ghrelin secretion in rats. Regul Pept. 2008;146(1-3):12-8. https://doi.org/10.1016/j.regpep.2007.07.005.

39. Zhao TJ, Sakata I, Li RL, Liang G, Richardson JA, Brown MS, et al. Ghrelin secretion stimulated by \{beta\}1-adrenergic receptors in cultured ghrelinoma cells and in fasted mice. Proc Natl Acad Sci USA. 2010;107(36):15868-73. https://doi.org/10.1073/ pnas.1011116107.

40. Cummings DE, Weigle DS, Frayo RS, Breen PA, Ma MK, Dellinger EP, et al. Plasma ghrelin levels after dietinduced weight loss or gastric bypass surgery. N Engl J Med. 2002;346(21):1623-30. https://doi.org/10.1056/NEJMoa012908.

41. Nagaya N, Uematsu M, Kojima M, Date Y, Nakazato M, Okumura $\mathrm{H}$, et al. Elevated circulating level of ghrelin in cachexia associated with chronic heart failure: relationships between ghrelin and anabolic/catabolic factors. Circulation. 2001;104(17):2034-8. https://doi.org/10.1161/hc4201.097836.

42. Kraemer RR, Castracane VD. Exercise and humoral mediators of peripheral energy balance: ghrelin and adiponectin. Exp Biol Med (Maywood). 2007;232(2):184-94.

43. Stensel D. Exercise, appetite and appetite-regulating hormones: implications for food intake and weight control. Ann Nutr Metab. 2010;57(Suppl 2):36-42. https://doi.org/10.1159/000322702.

44. King JA, Wasse LK, Stensel DJ, Nimmo MA. Exercise and ghrelin. A narrative overview of research. Appetite. 2013;68:83-91. https://doi.org/10.1016/j.appet.2013.04.018.

45. Moher D, Liberati A, Tetzlaff J, Altman DG, PRISMA Group. Preferred reporting items for systematic reviews and meta-analyses: the PRISMA statement. PLoS Med. 2009;6(7):e1000097. https://doi.org/10.1371/journal.pmed.1000097.

46. Dall R, Kanaley J, Hansen TK, Møller N, Christiansen JS, Hosoda $\mathrm{H}$, et al. Plasma ghrelin levels during exercise in healthy subjects and in growth hormone-deficient patients. Eur J Endocrinol. 2002;147(1):65-70. https://doi.org/10.1530/eje.0.14700 65 .

47. Kraemer RR, Durand RJ, Acevedo EO, Johnson LG, Kraemer GR, Hebert EP, et al. Rigorous running increases growth hormone and insulin-like growth factor-I without altering ghrelin. Exp Biol Med (Maywood). 2004;229(3):240-6. https://doi.org/ $10.1177 / 153537020422900304$

48. Zoladz JA, Konturek SJ, Duda K, Majerczak J, Sliwowski Z, Grandys M, et al. Effect of moderate incremental exercise, performed in fed and fasted state on cardio-respiratory variables and leptin and ghrelin concentrations in young healthy men. J Physiol Pharmacol. 2005;56(1):63-85.

49. Jürimäe J, Hofmann P, Jürimäe T, Palm R, Mäestu J, Purge P, et al. Plasma ghrelin responses to acute sculling exercises in elite male rowers. Eur J Appl Physiol. 2007;99(5):467-74. https://doi. org/10.1007/s00421-006-0370-y.

50. Erdmann J, Tahbaz R, Lippl F, Wagenpfeil S, Schusdziarra V. Plasma ghrelin levels during exercise - effects of intensity and duration. Regul Pept. 2007;143(1-3):127-35. https://doi.org/10. 1016/j.regpep.2007.05.002.

51. Marzullo P, Salvadori A, Brunani A, Verti B, Walker GE, Fanari $\mathrm{P}$, et al. Acylated ghrelin decreases during acute exercise in the lean and obese state. Clin Endocrinol (Oxf). 2008;69(6):970-1. https://doi.org/10.1111/j.1365-2265.2008.03275.x.

52. Unick JL, Otto AD, Goodpaster BH, Helsel DL, Pellegrini CA, Jakicic JM. Acute effect of walking on energy intake in overweight/obese women. Appetite. 2010;55(3):413-9. https://doi. org/10.1016/j.appet.2010.07.012.

53. Thomas GA, Kraemer WJ, Comstock BA, Dunn-Lewis C, Volek JS, Denegar CR, et al. Effects of resistance exercise and obesity level on ghrelin and cortisol in men. Metabolism. 2012;61(6):860-8. https://doi.org/10.1016/j.metabol.2011.10. 015 .

54. Crabtree DR, Blannin AK. Effects of exercise in the cold on Ghrelin, PYY, and food intake in overweight adults. Med Sci Sports Exerc. 2015;47(1):49-57. https://doi.org/10.1249/MSS. 0000000000000391.

55. Moraes C, Borges NA, Barboza J, Barros AF, Mafra D. Effects of acute resistance exercise on acyl-ghrelin and obestatin levels in hemodialysis patients: a pilot study. Ren Fail. 2015;37(10):338 42. https://doi.org/10.3109/0886022X.2015.1087805.

56. Larsen PS, Donges CE, Guelfi KJ, Smith GC, Adams DR, Duffield R. Effects of aerobic, strength or combined exercise on perceived appetite and appetite-related hormones in inactive middleaged men. Int J Sport Nutr Exerc Metab. 2017;27(5):389-98. https://doi.org/10.1123/ijsnem.2017-0144.

57. Ouerghi N, Brini S, Zaouali M, Feki M, Tabka Z, Bouassida A. Ghrelin is not altered after acute exercises at different intensities in overweight middle-aged individuals. Sci Sports. 2019;34(3):149-55. https://doi.org/10.1016/j.scispo.2018.08. 010 .

58. Beer NJ, Dimmock JA, Jackson B, Guelfi KJ. Interactions of sprint interval exercise and psychological need-support on subsequent food intake among physically inactive men and women. Appl Physiol Nutr Metab. 2020;45(8):835-44. https://doi.org/10. 1139/apnm-2019-0672.

59. Toshinai K, Kawagoe T, Shimbara T, Tobina T, Nishida Y, Mondal MS, et al. Acute incremental exercise decreases plasma ghrelin level in healthy men. Horm Metab Res. 2007;39(11):849-51. https://doi.org/10.1055/s-2007-991177.

60. Malkova D, McLaughlin R, Manthou E, Wallace AM, Nimmo MA. Effect of moderate-intensity exercise session on preprandial and postprandial responses of circulating ghrelin and appetite. Horm Metab Res. 2008;40(6):410-5. https://doi.org/10.1055/s2008-1058100.

61. Balaguera-Cortes L, Wallman KE, Fairchild TJ, Guelfi KJ. Energy intake and appetite-related hormones following acute aerobic and resistance exercise. Appl Physiol Nutr Metab. 2011;36(6):958-66. https://doi.org/10.1139/h11-121.

62. Becker GF, Macedo RC, Cunha Gdos S, Martins JB, Laitano O, Reischak-Oliveira A. Combined effects of aerobic exercise and high-carbohydrate meal on plasma acylated ghrelin and levels of hunger. Appl Physiol Nutr Metab. 2012;37(1):184-92. https:// doi.org/10.1139/h11-149.

63. Sim AY, Wallman KE, Fairchild TJ, Guelfi KJ. High-intensity intermittent exercise attenuates ad-libitum energy intake. Int J Obes (Lond). 2014;38(3):417-22. https://doi.org/10.1038/ijo. 2013.102.

64. Gholipour M, Kordi MR, Taghikhani M, Ravasi AA, Gaeini AA, Tabrizi A. Possible role for growth hormone in suppressing acylated ghrelin and hunger ratings during and after intermittent exercise of different intensities in obese individuals. Acta Med Iran. 2014;52(1):29-37. 
65. Metcalfe RS, Koumanov F, Ruffino JS, Stokes KA, Holman GD, Thompson D, et al. Physiological and molecular responses to an acute bout of reduced-exertion high-intensity interval training (REHIT). Eur J Appl Physiol. 2015;115(11):2321-34. https:// doi.org/10.1007/s00421-015-3217-6.

66. Howe SM, Hand TM, Larson-Meyer DE, Austin KJ, Alexander BM, Manore MM. No Effect of exercise intensity on appetite in highly trained endurance women. Nutrients. 2016;8(4):223. https://doi.org/10.3390/nu8040223.

67. Holliday A, Blannin AK. Very low volume sprint interval exercise suppresses subjective appetite, lowers acylated ghrelin, and elevates GLP-1 in overweight individuals: a pilot study. Nutrients. 2017;9(4):362. https://doi.org/10.3390/nu9040362.

68. Hunschede S, Schwartz A, Kubant R, Thomas SG, Anderson GH. The role of IL-6 in exercise-induced anorexia in normal-weight boys. Appl Physiol Nutr Metab. 2018;43(10):979-87. https://doi. org/10.1139/apnm-2018-0019.

69. Matos VAF, de Souza DC, Browne RAV, Dos Santos VOA, Medeiros ÍF, do Nascimento PRP, et al. A single session of lowvolume high-intensity interval and moderate-intensity continuous exercise elicits a transient reduction in ghrelin levels, but not in post-exercise energy intake in obese men. Arch Endocrinol Metab. 2020:2359-3997000000308. https://doi.org/10.20945/ 2359-3997000000308.

70. Leow S, Beer NJ, Dimmock JA, Jackson B, Alderson JA, Clarke MW, et al. The effect of antecedent exercise on the acute stress response and subsequent food consumption: a preliminary investigation. Physiol Behav. 229:113256. https://doi.org/10.1016/j. physbeh.2020.113256.

71. Jürimäe $J$, Jürimäe T, Purge P. Plasma ghrelin is altered after maximal exercise in elite male rowers. Exp Biol Med (Maywood). 2007;232(7):904-9.

72. Burns SF, Broom DR, Miyashita M, Mundy C, Stensel DJ. A single session of treadmill running has no effect on plasma total ghrelin concentrations. J Sports Sci. 2007;25(6):635-42. https:// doi.org/10.1080/02640410600831856.

73. Martins C, Morgan LM, Bloom SR, Robertson MD. Effects of exercise on gut peptides, energy intake and appetite. J Endocrinol. 2007;193(2):251-8. https://doi.org/10.1677/JOE-06-0030.

74. Sartorio A, Morpurgo P, Cappiello V, Agosti F, Marazzi N, Giordani C, et al. Exercise-induced effects on growth hormone levels are associated with ghrelin changes only in presence of prolonged exercise bouts in male athletes. J Sports Med Phys Fit. 2008;48(1):97-101.

75. Hagobian TA, Sharoff CG, Stephens BR, Wade GN, Silva JE, Chipkin SR, et al. Effects of exercise on energy-regulating hormones and appetite in men and women. Am J Physiol Regul Integr Comp Physiol. 2009;296(2):R233-42. https://doi.org/10. 1152/ajpregu.90671.2008

76. King JA, Wasse LK, Broom DR, Stensel DJ. Influence of brisk walking on appetite, energy intake, and plasma acylated ghrelin. Med Sci Sports Exerc. 2010;42(3):485-92. https://doi.org/10. 1249/MSS.0b013e3181ba10c4.

77. King JA, Wasse LK, Ewens J, Crystallis K, Emmanuel J, Batterham RL, et al. Differential acylated ghrelin, peptide YY3-36, appetite, and food intake responses to equivalent energy deficits created by exercise and food restriction. J Clin Endocrinol Metab. 2011;96(4):1114-21. https://doi.org/10.1210/jc.2010-2735.

78. Shiiya T, Ueno H, Toshinai K, Kawagoe T, Naito S, Tobina $\mathrm{T}$, et al. Significant lowering of plasma ghrelin but not desacyl ghrelin in response to acute exercise in men. Endocr $\mathrm{J}$. 2011;58(5):335-42. https://doi.org/10.1507/endocrj.k11e-021.

79. Plinta R, Olszanecka-Glinianowicz M, Drosdzol-Cop A, Chudek J, Skrzypulec-Plinta V. The effect of three-month pre-season preparatory period and short-term exercise on plasma leptin, adiponectin, visfatin, and ghrelin levels in young female handball and basketball players. J Endocrinol Investig. 2012;35(6):595601. https://doi.org/10.3275/8014.

80. Heden TD, Liu Y, Park Y, Dellsperger KC, Kanaley JA. Acute aerobic exercise differentially alters acylated ghrelin and perceived fullness in normal-weight and obese individuals. J Appl Physiol (1985). 2013;115(5):680-7. https://doi.org/10.1152/jappl physiol.00515.2013.

81. Tiryaki-Sonmez G, Ozen S, Bugdayci G, Karli U, Ozen G, Cogalgil S, et al. Effect of exercise on appetite-regulating hormones in overweight women. Biol Sport. 2013;30(2):75-80. https://doi.org/10.5604/20831862.1044220.

82. Douglas JA, King JA, Clayton DJ, Jackson AP, Sargeant JA, Thackray AE, et al. Acute effects of exercise on appetite, ad libitum energy intake and appetite-regulatory hormones in lean and overweight/obese men and women. Int J Obes (Lond). 2017;41(12):1737-44. https://doi.org/10.1038/ijo.2017.181.

83. Laursen TL, Zak RB, Shute RJ, Heesch MWS, Dinan NE, Bubak $\mathrm{MP}$, et al. Leptin, adiponectin, and ghrelin responses to endurance exercise in different ambient conditions. Temperature (Austin). 2017;4(2):166-75. https://doi.org/10.1080/23328940.2017. 1294235.

84. Broom DR, Stensel DJ, Bishop NC, Burns SF, Miyashita M. Exercise-induced suppression of acylated ghrelin in humans. J Appl Physiol (1985). 2007;102(6):2165-71. https://doi.org/10. 1152/japplphysiol.00759.2006.

85. Broom DR, Batterham RL, King JA, Stensel DJ. Influence of resistance and aerobic exercise on hunger, circulating levels of acylated ghrelin, and peptide YY in healthy males. Am J Physiol Regul Integr Comp Physiol. 2009;296(1):R29-35. https://doi.org/ 10.1152/ajpregu.90706.2008.

86. King JA, Wasse LK, Stensel DJ. The acute effects of swimming on appetite, food intake, and plasma acylated ghrelin. J Obes. 2011;2011: 351628. https://doi.org/10.1155/2011/351628.

87. Wasse LK, Sunderland C, King JA, Miyashita M, Stensel DJ. The influence of vigorous running and cycling exercise on hunger perceptions and plasma acylated ghrelin concentrations in lean young men. Appl Physiol Nutr Metab. 2013;38(1):1-6. https:// doi.org/10.1139/apnm-2012-0154.

88. Deighton K, Barry R, Connon CE, Stensel DJ. Appetite, gut hormone and energy intake responses to low volume sprint interval and traditional endurance exercise. Eur J Appl Physiol. 2013;113(5):1147-56. https://doi.org/10.1007/ s00421-012-2535-1.

89. Kawano H, Mineta M, Asaka M, Miyashita M, Numao S, Gando $\mathrm{Y}$, et al. Effects of different modes of exercise on appetite and appetite-regulating hormones. Appetite. 2013;66:26-33. https:// doi.org/10.1016/j.appet.2013.01.017.

90. Dorling JL, Clayton DJ, Jones J, Carter WG, Thackray AE, King $\mathrm{JA}$, et al. A randomized crossover trial assessing the effects of acute exercise on appetite, circulating ghrelin concentrations, and butyrylcholinesterase activity in normal-weight males with variants of the obesity-linked FTO rs 9939609 polymorphism. Am J Clin Nutr. 2019;110(5):1055-66. https://doi.org/10.1093/ajcn/ nqz188.

91. Ghanbari-Niaki A. Ghrelin and glucoregulatory hormone responses to a single circuit resistance exercise in male college students. Clin Biochem. 2006;39(10):966-70. https://doi.org/10. 1016/j.clinbiochem.2006.05.009.

92. King JA, Miyashita M, Wasse LK, Stensel DJ. Influence of prolonged treadmill running on appetite, energy intake and circulating concentrations of acylated ghrelin. Appetite. 2010;54(3):492-8. https://doi.org/10.1016/j.appet.2010.02.002.

93. Vatansever-Ozen S, Tiryaki-Sonmez G, Bugdayci G, Ozen G. The effects of exercise on food intake and hunger: relationship with acylated ghrelin and leptin. J Sports Sci Med. 2011;10(2):283-91. 
94. Christ ER, Zehnder M, Boesch C, Trepp R, Mullis PE, Diem P, et al. The effect of increased lipid intake on hormonal responses during aerobic exercise in endurance-trained men. Eur J Endocrinol. 2006;154(3):397-403. https://doi.org/10.1530/eje.1. 02106.

95. Jürimäe J, Rämson R, Mäestu J, Purge P, Jürimäe T, Arciero PJ, von Duvillard SP. Plasma visfatin and ghrelin response to prolonged sculling in competitive male rowers. Med Sci Sports Exerc. 2009;41(1):137-43. https://doi.org/10.1249/MSS.0b013 e31818313e6.

96. Russel RR, Willis KS, Ravussin E, Larson-Meyer ED. Effects of endurance running and dietary fat on circulating ghrelin and peptide YY. J Sports Sci Med. 2009;8(4):574-83.

97. Saghebjoo M, Hedayati M, Fahimi Y, Ilbeigi S. Plasma acylated ghrelin response to one session circuit resistance exercise in fasted and high carbohydrate meal in healthy young men. Int $\mathbf{J}$ Endocrinol Metab. 2013;11(4): e8568. https://doi.org/10.5812/ ijem. 8568 .

98. Rämson R, Jürimäe J, Jürimäe T, Mäestu J. The influence of increased training volume on cytokines and ghrelin concentration in college level male rowers. Eur J Appl Physiol. 2008;104(5):839-46. https://doi.org/10.1007/ s00421-008-0839-y.

99. Hedayati M, Saghebjoo M, Ghanbari-Niaki A. Effects of circuit resistance training intensity on the plasma ghrelin to obestatin ratios in healthy young women. Int J Endocrinol Metab. 2012;10(2):475-9. https://doi.org/10.5812/ijem.2459.

100. Morishima T, Kurihara T, Hamaoka T, Goto K. Whole body, regional fat accumulation, and appetite-related hormonal response after hypoxic training. Clin Physiol Funct Imaging. 2014;34(2):90-7. https://doi.org/10.1111/cpf.12069.

101. Rämson R, Jürimäe J, Jürimäe T, Mäestu J. The effect of 4-week training period on plasma neuropeptide $\mathrm{Y}$, leptin and ghrelin responses in male rowers. Eur J Appl Physiol. 2012;112(5):187380. https://doi.org/10.1007/s00421-011-2166-y.

102. Cho GJ, Han SW, Shin JH, Kim T. Effects of intensive training on menstrual function and certain serum hormones and peptides related to the female reproductive system. Medicine (Baltimore). 2017;96(21): e6876. https://doi.org/10.1097/MD.0000000000 006876 .

103. Tremblay A, Dutheil F, Drapeau V, Metz L, Lesour B, Chapier R, et al. Long-term effects of high-intensity resistance and endurance exercise on plasma leptin and ghrelin in overweight individuals: the RESOLVE Study. Appl Physiol Nutr Metab. 2019;44(11):1172-9. https://doi.org/10.1139/apnm-2019-0019.

104. Liao J, Huang J, Wang S, Xiang M, Wang D, Deng H, et al. Effects of exercise and diet intervention on appetite-regulating hormones associated with miRNAs in obese children. Eat Weight Disord. 2020. https://doi.org/10.1007/s40519-020-00869-9.

105. Jones TE, Basilio JL, Brophy PM, McCammon MR, Hickner RC. Long-term exercise training in overweight adolescents improves plasma peptide YY and resistin. Obesity (Silver Spring). 2009;17(6):1189-95. https://doi.org/10.1038/oby.2009.11.

106. Martins C, Kulseng B, King NA, Holst JJ, Blundell JE. The effects of exercise-induced weight loss on appetite-related peptides and motivation to eat. J Clin Endocrinol Metab. 2010;95(4):1609-16. https://doi.org/10.1210/jc.2009-2082.

107. Guelfi KJ, Donges CE, Duffield R. Beneficial effects of 12 weeks of aerobic compared with resistance exercise training on perceived appetite in previously sedentary overweight and obese men. Metabolism. 2013;62(2):235-43. https://doi.org/10.1016/j. metabol.2012.08.002.

108. Gibbons C, Blundell JE, Caudwell P, Webb DL, Hellström PM, Näslund $\mathrm{E}$, et al. The role of episodic postprandial peptides in exercise-induced compensatory eating. J Clin Endocrinol Metab. 2017;102(11):4051-9. https://doi.org/10.1210/jc.2017-00817.
109. Bowyer KP, Carson JA, Davis JM, Wang X. The influence of exercise training dose on fasting acylated ghrelin concentration in older women. J Behav Med. 2019;42(3):567-72. https://doi. org/10.1007/s10865-018-9990-z.

110. Fico BG, Alkatan M, Tanaka H. No changes in appetite-related hormones following swimming and cycling exercise interventions in adults with obesity. Int J Exerc Sci. 2020;13(2):1819-25.

111. Yu AP, Ugwu FN, Tam BT, Lee PH, Lai CW, Wong CSC, et al. One year of yoga training alters ghrelin axis in centrally obese adults with metabolic syndrome. Front Physiol. 2018;9:1321. https://doi.org/10.3389/fphys.2018.01321.

112. Leidy HJ, Gardner JK, Frye BR, Snook ML, Schuchert MK, Richard EL, et al. Circulating ghrelin is sensitive to changes in body weight during a diet and exercise program in normal-weight young women. J Clin Endocrinol Metab. 2004;89(6):2659-64. https://doi.org/10.1210/jc.2003-031471.

113. Foster-Schubert KE, McTiernan A, Frayo RS, Schwartz RS, Rajan KB, Yasui Y, et al. Human plasma ghrelin levels increase during a one-year exercise program. J Clin Endocrinol Metab. 2005;90(2):820-5. https://doi.org/10.1210/jc.2004-2081.

114. Kelishadi R, Hashemipour M, Mohammadifard N, Alikhassy H, Adeli K. Short- and long-term relationships of serum ghrelin with changes in body composition and the metabolic syndrome in prepubescent obese children following two different weight loss programs. Clin Endocrinol (Oxf). 2008;69(5):721-9. https:// doi.org/10.1111/j.1365-2265.2008.03220.x.

115. Mizia-Stec K, Zahorska-Markiewicz B, Olszanecka-Glinianowicz M, Janowska J, Mucha Z, Holecki M, et al. Ghrelin as a potential blood pressure reducing factor in obese women during weight loss treatment. Endokrynol Pol. 2008;59(3):207-11.

116. Konopko-Zubrzycka M, Baniukiewicz A, Wróblewski E, Kowalska I, Zarzycki W, Górska M, Dabrowski A. The effect of intragastric balloon on plasma ghrelin, leptin, and adiponectin levels in patients with morbid obesity. J Clin Endocrinol Metab. 2009;94(5):1644-9. https://doi.org/10.1210/jc.2008-1083.

117. Cederberg H, Rajala U, Koivisto VM, Jokelainen J, Surcel HM, Keinänen-Kiukaanniemi S, et al. Unacylated ghrelin is associated with changes in body composition and body fat distribution during long-term exercise intervention. Eur J Endocrinol. 2011;165(2):243-8. https://doi.org/10.1530/EJE-11-0334.

118. Gueugnon C, Mougin F, Nguyen NU, Bouhaddi M, NicoletGuénat M, Dumoulin G. Ghrelin and PYY levels in adolescents with severe obesity: effects of weight loss induced by long-term exercise training and modified food habits. Eur $\mathbf{J}$ Appl Physiol. 2012;112(5):1797-805. https://doi.org/10.1007/ s00421-011-2154-2.

119. Ueda SY, Miyamoto T, Nakahara H, Shishido T, Usui T, Katsura $\mathrm{Y}$, et al. Effects of exercise training on gut hormone levels after a single bout of exercise in middle-aged Japanese women. Springerplus. 2013;2(1):83. https://doi.org/10.1186/2193-1801-2-83.

120. Markofski MM, Carrillo AE, Timmerman KL, Jennings K, Coen PM, Pence BD, et al. Exercise training modifies ghrelin and adiponectin concentrations and is related to inflammation in older adults. J Gerontol A Biol Sci Med Sci. 2014;69(6):675-81. https://doi.org/10.1093/gerona/glt132.

121. Campos RM, de Mello MT, Tock L, Silva PL, Masquio DC, de Piano A, et al. Aerobic plus resistance training improves bone metabolism and inflammation in adolescents who are obese. $\mathbf{J}$ Strength Cond Res. 2014;28(3):758-66. https://doi.org/10.1519/ JSC.0b013e3182a996df.

122. Kim HH, Kim YJ, Lee SY, Jeong DW, Lee JG, Yi YH, et al. Interactive effects of an isocaloric high-protein diet and resistance exercise on body composition, ghrelin, and metabolic and hormonal parameters in untrained young men: a randomized clinical trial. J Diabetes Investig. 2014;5(2):242-7. https://doi. org/10.1111/jdi.12148. 
123. Mason C, Xiao L, Imayama I, Duggan CR, Campbell KL, Kong A, et al. The effects of separate and combined dietary weight loss and exercise on fasting ghrelin concentrations in overweight and obese women: a randomized controlled trial. Clin Endocrinol (Oxf). 2015;82(3):369-76. https://doi.org/10.1111/cen.12483.

124. Moraes C, Marinho S, Lobo JC, Stockler-Pinto MB, Barros AF, Jacobson LV, et al. Effects of resistance exercise training on acyl-ghrelin and obestatin levels in hemodialysis patients. Ren Fail. 2015;37(5):851-7. https://doi.org/10.3109/0886022X.2015. 1033634.

125. Kang SJ, Kim JH, Gang Z, Yook YS, Yoon JR, Ha GC, et al. Effects of 12-week circuit exercise program on obesity index, appetite regulating hormones, and insulin resistance in middleaged obese females. J Phys Ther Sci. 2018;30(1):169-73. https:// doi.org/10.1589/jpts.30.169.

126. King JA, Deighton K, Broom DR, Wasse LK, Douglas JA, Burns SF, et al. Individual variation in hunger, energy intake, and ghrelin responses to acute exercise. Med Sci Sports Exerc. 2017;49(6):1219-28. https://doi.org/10.1249/MSS.0000000000 001220 .

127. De Vriese C, Gregoire F, Lema-Kisoka R, Waelbroeck M, Robberecht P, Delporte C. Ghrelin degradation by serum and tissue homogenates: identification of the cleavage sites. Endocrinology. 2004;145(11):4997-5005. https://doi.org/10.1210/en.2004-0569.
128. Wu R, Dong W, Ji Y, Zhou M, Marini CP, Ravikumar TS, Wang P. Orexigenic hormone ghrelin attenuates local and remote organ injury after intestinal ischemia-reperfusion. PLoS One. 2008;3(4): e2026. https://doi.org/10.1371/journal.pone.0002026.

129. Yang J, Brown MS, Liang G, Grishin NV, Goldstein JL. Identification of the acyltransferase that octanoylates ghrelin, an appetite-stimulating peptide hormone. Cell. 2008;132(3):387-96. https://doi.org/10.1016/j.cell.2008.01.017.

130. Hazell TJ, Islam H, Townsend LK, Schmale MS, Copeland JL. Effects of exercise intensity on plasma concentrations of appetite-regulating hormones: potential mechanisms. Appetite. 2016;98:80-8. https://doi.org/10.1016/j.appet.2015.12.016.

131. Kamegai J, Tamura H, Shimizu T, Ishii S, Sugihara H, Oikawa S. Effects of insulin, leptin, and glucagon on ghrelin secretion from isolated perfused rat stomach. Regul Pept. 2004;119(1-2):77-81. https://doi.org/10.1016/j.regpep.2004.01.012.

132. Williams DL, Cummings DE. Regulation of ghrelin in physiologic and pathophysiologic states. J Nutr. 2005;135(5):1320-5. https://doi.org/10.1093/jn/135.5.1320.

133. McLaughlin T, Abbasi F, Lamendola C, Frayo RS, Cummings DE. Plasma ghrelin concentrations are decreased in insulinresistant obese adults relative to equally obese insulin-sensitive controls. J Clin Endocrinol Metab. 2004;89(4):1630-5. https:// doi.org/10.1210/jc.2003-031572.

\section{Authors and Affiliations}

\section{Nejmeddine Ouerghi ${ }^{1,2}$ (1) Moncef Feki ${ }^{2}\left(\mathbb{D} \cdot\right.$ Nicola Luigi Bragazzi $^{3} \cdot$ Beat Knechtle $^{4,5} \cdot$ Lee Hill $^{6}$. Pantelis T. Nikolaidis ${ }^{7} \cdot$ Anissa Bouassida ${ }^{1}$}

Nejmeddine Ouerghi

najm_ouerghi@hotmail.com

Moncef Feki

monssef.feki@gmail.com

Nicola Luigi Bragazzi

robertobragazzi@gmail.com

Lee Hill

hill114@mcmaster.ca

Pantelis T. Nikolaidis

pademil@hotmail.com

Anissa Bouassida

bouassida_anissa@yahoo.fr

1 High Institute of Sport and Physical Education of Kef, UR13JS01, University of Jendouba, 7100 Kef, Tunisia
2 Faculty of Medicine of Tunis, Rabta Hospital, LR99ES11, University of Tunis El Manar, 1007 Tunis, Tunisia

3 Postgraduate School of Public Health, Department of Health Sciences (DISSAL), University of Genoa, 16132 Genoa, Italy

4 Medbase St. Gallen Am Vadianplatz, Vadianstrasse 26, 9001 St. Gallen, Switzerland

5 Institute of Primary Care, University of Zurich, Zurich, Switzerland

6 Division of Gastroenterology and Nutrition, Department of Pediatrics, McMaster University, Hamilton L8S 4L8, Canada

7 School of Health and Caring Sciences, University of West Attica, Athens, Greece 